\title{
AN INITIAL INQUIRY INTO THE RESPONSIBILITY TO DISCLOSE MARKET INFORMATION*
}

\author{
ARTHUR FleISCher, JR. $\dagger$ \\ ROBERT H. MUNDHEIM†† \\ JOHN C. MURPHY, JR. $\dagger \dagger$ †
}

\section{MARKET INFORMATION AND RULE 10b-5}

\section{A. Market Information}

A company discovers that land it owns contains substantial mineral deposits which can be commercially exploited. Officers and directors of the company who are aware of this discovery purchase the company's stock in the market before the information is made public. These facts describe a by now familiar inside information situation. ${ }^{1}$ When the information is made public, the market will know that the value of the company's assets and its earning power have been substantially augmented and the price of the stock will adjust to reflect the increase in the value of the company. Purchase of the stock by directors and officers of the company under these circumstances violates the antifraud provisions of rule $10 \mathrm{~b}-5^{2}$ promulgated under Section $10(\mathrm{~b})$ of the Securities Exchange Act of $1934 .^{3}$

The following facts describe another situation in which material, non-public information is present. The president of ABC Company Iearns from Giant Brokerage Firm's analyst, who interviews him about

* This Article bears a date of February 26, 1973. Some citations have been updated editorially.

† B.A. 1953, LL.B. 1958, Yale University. Member, New York Bar.

i† Fred Carr Professor of Law, University of Pennsylvania; Director, University of Pennsylvania Law School Center for Study of Financial Institutions. B.A. 1954, LL.B. 1957, Harvard University. Member, New York Bar.

itt A.B. 1967, Georgetown University; J.D. 1971, University of Pennsylvania. Member, California Bar. The major part of my contribution to this Article was prepared while I was a Fellow at the University of Pennsylvania Law School Center for Study of Financial Institutions.

1 See SEC v. Texas Gulf Sulphur Co., 401 F.2d 833 (2d Cir. 1968), rev'g and aff'g in part 258 F. Supp. 262 (S.D.N.Y. 1966), cert. denied, 394 U.S. 976 (1969). An early Massachusetts case contains striking parallels to the facts in Texas Gulf Sulphur. Goodwin v. Agassiz, 283 Mass. 358, 186 N.E. 659 (1933).

2 SEC v. Texas Gulf Sulphur Co., 401 F.2d 833 (2d Cir. 1968), cert. denied, 394 U.S. 976 (1969). The court in Goodwin $v$. Agassiz affirmed a dismissal of plaintiff's complaint under Massachusetts law where defendant's purchases were made on the Boston Stock Exchange and plaintiff did not show reliance on defendant's failure to disclose the information he had concerning the existence of copper deposits on the company's land.

315 U.S.C. $\$ 78 \mathrm{j}(\mathrm{b})$ (1970) [hereinafter cited as 1934 Act], Rule 10b-5, 17 C.F.R. $\S 240.10 \mathrm{~b}-5$ (1972). 
$A B C$, that Giant Brokerage will shortly publish a favorable analysis of $\mathrm{ABC}$, including a recommendation to buy the stock. That report is based on generally available facts. ABC stock is thinly traded so that the appearance of the Giant Brokerage report and recommendation is "reasonably certain" to have a substantial impact on the price of ABC stock. Can the president of $\mathrm{ABC}$ buy stock of the company prior to the appearance of the Giant Brokerage report and recommendation without violating rule $10 \mathrm{~b}-5$ ?

In this example nothing happens to the company which has any impact on the value of its assets or its earning power. Nevertheless, any person buying $A B C$ stock who possesses information about the Giant Brokerage report and recommendation will have an advantage over sellers of the stock who are unaware of the information. Measured by the immediate impact on stock price alone, the two events may be of equal significance.

The second situation typifies those cases where the undisclosed information is market information. For our purposes, market information refers to information about events or circumstances which affect the market for a company's securities but which do not affect the company's assets or earning power. Situations involving market information abound. Knowledge that mutual funds experienced net redemptions over a recent period has affected market prices generally. In other cases market information affects only the stock of a particular company. Certain persons may know that a tender offer for Target Company will shortly be made at a premium over the present market price. Certain persons may know that they or others intend to purchase or sell a sufficiently large number of shares of $A B C$ Company to affect substantially the present market price of the stock. ${ }^{4}$ Certain persons may know that ABC Company will shortly split its stock. ${ }^{5}$

4 See Reed v. Riddle Airlines, 266 F,2d 314, 315, 319 (5th Cir. 1959) (insider failed to disclose that a wealthy individual was interested in purchasing shares, where those purchases caused an increase in price of the stock). Such information also would be important where the purchases remove a block of stock overhanging the market and depressing the price of the security, see, e.g., Rogen v. Ilikon Corp., 361 F.2d 260, 264 (1st Cir. 1966); Matarese v. Aero-Chatillon Corp., [1971-1972 Transfer Binder] CCH FED. SEC. L. REP. II 93,322 at 91,731 (S.D.N.Y. 1971).

5 See, e.g., Hausman, West \& Largay, Stock Splits, Price Changes, and Trading Profits: A Synthesis, 44 J. Bus. 69 (1971); Kimball \& Papera, Effect of Stock Splits on Short-Term Market Prices, 20 Fin. ANat. J. 75 (1964); Rieke, Selling on the News, 44 Barron's, Nov. 30, 1964, at 9. If the stock split is not accompanied by a proportionate reduction in the dividend per share, the effect of the split would be to increase the dividend payment. Increases in dividends normally result in an increase in the stock price. Even a stock split which does not carry with it a rise in the dividend rate may have a similar effect. The reduction in the price of the stock, together with the greater number of shares outstanding, frequently attracts greater purchasing power, thus causing the price of the stock to rise. Wall St. J., Jan. 3, 1972, at 1, col. 6 (east coast ed.).

In Hafner v. Forest Laboratories, Inc., 345 F.2d 167 (2d Cir. 1965), a corporation's failure to disclose an impending $4 \%$ stock dividend to a shareholder from whom it repur- 
In the last few years, there has been increasing regulatory emphasis on the importance of adequate disclosure of market information. Recently adopted rule 144, which governs the resale of "restricted" securities, conditions its applicability on the seller filing a Form 144 with the SEC at the time of placing the sell order. ${ }^{6}$ Form 144 asks for information about the seller's intention to sell, the amount of securities to be sold, the market place in which the securities will be sold and the name of the selling broker. Since the Form is a public document, market makers and others are provided access to information about the available supply of and potential selling pressure on the particular security. ${ }^{7}$ In addition, the SEC has begun requiring disclosure, at least in the case of initial public offerings, of the amount of stock of a company that could be resold without registration under the 1933 Act after the effective date of the registration statement. ${ }^{8}$ Presumably the

chased shares was held not to be a violation of $\S 10(\mathrm{~b})$ and rule $10 \mathrm{~b}-5$. The district court based its conclusion on the fact that stock dividends have no intrinsic value and give the shareholder no greater ownership interest in the corporation. The Second Circuit affirmed the district court's holding on the facts of the case, but indicated that in some circumstances knowledge of a stock dividend might be material information. Id. at 168. The Hafner decision has been cited as recognizing the potential market importance of stock dividends and stock splits. 1 A. BROMIBERG, SECURITIES IAW-FraUd: SEC RULE $10 \mathrm{~b}-5$, \& 7.4(4) (b), at $170.1 \mathrm{n} .123$ (1969). Cf. Weitzen v. Kearns, 271 F. Supp. 616, 618 (S.D.N.Y. 1967).

${ }^{6}$ SEC Securities Act Rule 144(h), 37 Fed. Reg. 591, 596 (1972). Proposed rule 144(h) required that the seller file a notice of intention to sell at least ten days in advance of any sale. That provision was designed to produce market information. For an analysis of the adverse impact on the seller of having to supply such information, see Matteson, Dispositions of Securities Under Proposed Rule 144, in PLI 3D ANNUAL INSTITUTE ON SECURITIES REGULATION 35, 50 (R. Mundheim \& A. Fleischer eds. 1972) [hereinafter cited as 3D ANNUAT, INSTITUTE].

7 The SEC requires that a stockholder selling securities pursuant to a registration statement under the Securities Act of 1933 furnish his identity and the amount of stock proposed to be sold. See, e.g., Form S-1, Item 19, Instruction 3, 1 CCH FED. SEc. L. REP. If 8210. Under the American Law Institute's tentative draft of the Federal Securities Code, similar market information would in effect be required of all sellers of securities, whether or not control persons and whether or not selling "restricted" securities, if their sales are effected by means of a "distribution" (a non-trading transaction). ALI FED. SECURITIES CODE $\$ \$ 227,509$ (Tent. Draft No. 1, 1971).

8 For example, the prospectus of Strother Drug Company, dated November 28, 1972, stated on the cover page:

Additional outstanding shares available for public sale-Holders of 101,916 shares of the Company's outstanding shares of common stock not included in this offering are free to sell their stock without limitation on the open market at the present time. Holders of 236,820 shares who would otherwise be free to sell their stock without limitation on the open market have agreed not to sell any shares for a period of 90 days following the date of this prospectus and holders of all of these shares have advised the Company that they have no present intention of disposing of their shares during the twelve-month period following the date of this prospectus. Holders of an additional 241,264 shares who have also agreed not to sell their shares for a period of 90 days following the date of this prospectus will be free to sell their shares subject to regulatory limitations on the amounts that may be sold and the methods of sale following such 90-day period. Holders of these shares have advised the Company that depending upon personal circumstances and the state of the market, it is possible that sales might be made within the twelve-month period following the date of this prospectus. Under existing regulations such persons could sell up to 31,200 shares during such period. Sales by existing stockholders could have a significant impact upon any 
intended purpose of this disclosure is to make investors aware of the fact that stockholders of the registrant, who have been essentially locked in while the company was privately held, are now free to resell and, in so doing, may adversely affect the market price of the stock. In addition, the information disclosed may furnish some idea of the prospective "float" for the company's securities. Further, the SEC's proposals relating to hot issues include a requirement that preliminary prospectuses and final prospectuses of certain issues disclose an estimate of the approximate percentage of an offering which will be placed with the principal underwriter's discretionary accounts. ${ }^{9}$ This requirement is designed to give investors in these issues material information about the supply of securities actually available to the public. ${ }^{10}$ The SEC has also sought to secure disclosure about the nature of the market in a company's securities, at least when known facts indicate the absence of an established trading market. ${ }^{11}$

In addition to requiring affirmative disclosure of market information in certain circumstances, the SEC has been investigating trading by brokers and their customers on the basis of knowledge that a research report or newspaper article would shortly be published. ${ }^{12}$ Moreover, the SEC is seeking an injunction in a situation involving a pattern of stock purchases by a financial columnist prior to the publication of his column recommending purchase of these stocks. ${ }^{13}$ The chief trial

trading market which might develop subsequent to this offering. The expressions of intent described above were obtained orally, are not legally enforceable and are subject to change at any moment. See "Selling Stockholders-Outstanding Shares Available for Public Sale."

In Birdman v. Electro-Catheter Corp., [Current] CCH FED. SEc. L. REP. II 93,934 (E.D. Pa., Jan. 18, 1973), the district court held, in denying defendant's motion for summary judgment, that a company violated rule $10 \mathrm{~b}-5$ and $\$ 11$ of the 1933 Act, 15 U.S.C. $\$ 77 \mathrm{k}(1970)$, in failing to disclose the potential market impact of the contemplated sale of restricted securities shortly after a public offering by the issuer. The registration statement allegedly failed to disclose that two shareholders intended to sell their shares of the issuer's common stock, after the public offering by the issuer. The shares intended to be sold amounted to more than $25 \%$ of the issuer's offering.

${ }^{9}$ SEC Securities Act Release No. 5276 (July 26, 1972).

10 SEC Securities Act Release No. 5274 (July 26, 1972).

11 Guideline 13, SEC Securities Act Release No. 4936 (July 26, 1961). See also Guideline 45 , requiring supplemental information as to the over-the-counter market for securities to be registered, including the aggregate number of shares transferred on the records of the registrant during a recent six-month period and the names of the most active market makers during that period. For suggestions by then Commissioner Richard $B$. Smith that the forms of the SEC, under both the 1933 and 1934 Acts, should contain further disclosures relating to information about the market for a company's securities, see Speech before the General Practice Conference on Securities Regulation of the Philadelphia Bar Association and the Pennsylvania Bar Institute, in Philadelphia, Pennsylvania, December 9, 1967.

12 See Greer, Cases on Tips Smudge Street's Image Further, Washington Post, Dec. $18,1972, \S D$ at 11 , col. 1. A fuller description of the SEC's concern with the unfair use of market information appears in SEC Exchange Act Release No. 9950, at 114-29 (Jan. 16, 1973).

13 See SEC v. Campbell, Civ. No. 72-1684-WMD (C.D. Cal., July 24, 1972); notes 110-26 infra \& accompanying text. 
counsel of the New York Regional Office of the SEC summarized SEC activity in this area by stating:

From all this one might conclude that notwithstanding its historical development thus far the application of Section 10 (b) to the unfair use of material, non-public information should not be restricted to information which emanates from a corporate source nor need it necessarily deal with a corporate issuer or its affairs. It should apply with equal force to the use of any information in the securities marketplace which either should be or is about to be made public, as long as the publication of the information might affect the decision of a reasonable investor. ${ }^{14}$

\section{B. Scope of Rule 10b-5}

Rule $10 \mathrm{~b}-5$ prohibits any person, whether or not he is what has been called an insider, from telling a material lie or half-truth in connection with the purchase or sale of a security. ${ }^{15}$ It is not necessary that the lie or half-truth be about the company. ${ }^{16}$ For example, the SEC has taken the position that a broker who knows of an impending tender offer at above current market prices cannot advise his customers to sell into the market. ${ }^{17} \mathrm{~A}$ fortiori it would be a violation of rule $10 \mathrm{~b}-5$ for any person to induce the purchase of a company's securities by falsely representing that a large mutual fund will begin a major acquisition program of the company's securities on the following day. ${ }^{18}$

More difficult questions arise in cases where a person buying or

14 Peloso, SEC Rule 10b-5 and Outside Information, 168 N.Y.L.J., Dec. 11, 1972, at 32,34 .

15 Rule 10b-5(2) states that it shall be unlawful for any person

to make any untrue statement of a material fact or to omit to state a material fact necessary in order to make the statement made, in the light of the circumstances under which they were made, not misleading . . . in connection with the purchase or sale of any security.

17 C.F.R. \& $240.10 \mathrm{~b}-5(2)(1972)$.

16 See, e.g., Errion v. Connell, 236 F.2d 447 (9th Cir. 1956); Fleischer, Securities Trading and Corporate Information Practices; The Implications of the Texas Gulf Sul phur Proceeding, 51 VA. L. REv. 1271, 1285 (1965).

17 Brief of SEC, Pacific Ins. Co. v. Blot, 267 F. Supp. 956 (S.D.N.Y. 1967) ; M.S. Wien \& Co., 23 S.E.C. 735, 746-54 (1946) (dictum) (tender offer impending at price substantially above market). See also Indiana State Sec. Corp., 38 S.E.C. 118 (1957) (dealer sold stock by means of a prospectus showing offering price to be $\$ 6$, without disclosing the stock was trading in the market at $3-1 / 2$ bid, $4-1 / 2$ asked).

18 This fact pattern is almost the converse of that presented by one of the early 10b-5 cases. In Kardon v. National Gypsum Co., 73 F. Supp. 798 (E.D. Pa. 1947), two of the four shareholders of a small Michigan paper company arranged to sell the assets of the company and an affiliate to National Gypsum. After the contract had been signed, these two shareholders purchased the 50\% interest of the other shareholders at a price substantially below one-half of the sale price negotiated with National Gypsum. The court found that the two shareholders had lied when asked whether they had made any agreement for the sale of the stock or the assets, and ordered the purchasing shareholders to account for the profits realized by them. Cf. Courtland v. Walston \& Co., Inc., [19711972 Transfer Binder] CCH FED. SEC. L. REP. II 93,378 (S.D.N.Y. 1972). 
selling securities fails to disclose material, non-public information which he possesses. The problem in the silence cases is to identify the circumstances which trigger a duty to come forward with information. In the rule $10 \mathrm{~b}-5$ context the concept of materiality appears to be applied more restrictively in imposing liability for failure to fulfill an affirmative obligation to disclose than in imposing liability with respect to a misstatement or half-truth. ${ }^{19}$

\section{Materiality}

A responsibility to come forward with information has typically been imposed only when the undisclosed event has a significant and long-term impact on the company. However, market information frequently relates to an event which has only passing effect. It could be argued that, unlike information about the company which would be important in protecting long-term investors, market information is primarily relevant to short-term traders. If the federal securities laws' concern for the protection of the investor relates primarily to long-term investors, ${ }^{20}$ courts should be more reluctant to impose duties of affirmative disclosure in connection with market information than they are with respect to information about the company.

It is unlikely, however, that courts will give much weight to this distinction between market information and information about the company. The Court of Appeals for the Second Circuit in Texas Gulf Sulphur firmly rejected the notion that the federal securities laws seek to protect only the long-term or conservative investor. In reviewing the district court's test of materiality, the circuit court reminded the district court that:

The speculators and chartists of Wall and Bay Streets are also "reasonable" investors entitled to the same legal protection afforded conservative traders. ${ }^{21}$

Even if the federal securities laws accorded different degrees of protection to long-term investors and short-term traders, it is hard, in any

19 This conclusion is reflected in the American Iaw Institute's tentative draft of the Federal Securities Code. Compare ALI FeD. SecurITIES CoDE \& 256 (Tent. Draft No. 2, 1973) with id. $\$ \$ 1303(\mathrm{a})$, (c).

20 Henry Manne's defense of insider trading is based in part on his view that longterm investors should be the primary objects of SEC solicitude. See H. MANNE, INSIDER TRADING AND THE STOCK MARKET (1966); Manne, In Defense of Insider Trading, HaRv. Bus. Rev., Nov.-Dec. 1966, at 113, 114.

21 SEC v. Texas Gulf Sulphur Co., 401 F.2d 833, 849 (2d Cir. 1968), cert. denied, 394 U.S. 976 (1969) (footnote omitted). See Investors Diversified Services, Inc.'s Statement of Policy With Respect to Receipt and Use of Material Inside (Non-Public) Information, appended to SEC v. Lum's Inc., No. 70-5280 (S.D.N.Y. Nov. 9, 1972) (information is material if its dissemination "is likely to affect the market price of any of the company's securities ... or is likely to be considered important by reasonable investors, including reasonable speculative investors, in determining whether to trade in such securities"). 
given case, to determine whether the investors who have been harmed are short-term or long-term investors. ${ }^{22}$ Further, in many cases, market information has more than a short-term effect. For example, when a company becomes recognized by an influential brokerage house, the market for the stock may achieve a long-term improvement in price.

Nevertheless, courts should be cautious in finding that any particular item of market information is material, because many factors determine market price at any particular time. Knowledge that Conglomerate Company intends within the week to make a tender offer for Target Company's stock at a $20 \%$ premium over present market price may be sufficiently certain (in terms of probability of occurrence and impact on price) to be considered material. On the other hand, the effect of Giant Brokerage Firm's report and recommendation on the market price of $\mathrm{ABC}$ stock will often be much less certain. The effect will depend in large part on the depth of the market in $A B C$ stock and on market conditions in general. If the recommendation appears along with Giant Brokerage Firm recommendations of a number of stocks, the force of the $\mathrm{ABC}$ recommendation may be diluted. In addition, investor reactions to any particular recommendation are hard to predict. Other brokerage firms may be taking a negative view of $A B C$ stock-or such a strongly favorable view on XYZ stock that customers who hold $\mathrm{ABC}$ stock would be induced to sell it to raise funds for investment in XYZ.

\section{Special Relationship}

The duty to disclose material, non-public information has not been imposed on every person possessing this type of information. Traditionally, this obligation has been limited to persons with a special relationship to the company affected by the information. Restrictions on the securities trading of this class of persons reflect notions of fiduciary responsibility developed under state and federal law. ${ }^{23}$ Cady, Roberts, one of the landmark cases on insider trading, spells out this approach. It reasoned:

Analytically, the obligation [to disclose material, non-public information prior to trading] rests on two principal elements; first, the existence of a relationship giving access, directly or indirectly, to information intended to be available only for a corporate purpose and not for the personal benefit of anyone, and second, the inherent unfairness involved where a party

22 See Schotland, Unsafe At Any Price: A Reply to Manne, Insider Trading and the Stock Market, 53 VA. L. REv. 1425, 1447-48 (1967).

28 The relationship between common law doctrines of fiduciary responsibility and the development of the law under rule $10 \mathrm{~b}-5$ is summarized in $3 \mathrm{~L}$. LOSS, SEcuriTIES REGULATTON 1445-53 (2d ed. 1961); 6 id. 355\%-72 (1969). 
takes advantage of such information knowing it is unavailable to those with whom he is dealing. ${ }^{24}$

The Cady, Roberts analysis of the reason for implying a duty to disclose has served as a model for judicial and administrative opinions and legal commentary for more than a decade. In its en banc decision in Texas Gulf Sulphur, the Court of Appeals for the Second Circuit described the Cady, Roberts analysis as the "essence" of rule $10 \mathrm{~b}-5 .^{25}$ Based upon traditional analysis, and assuming that the information was material, the president of $A B C$ who learns, because of his position with $\mathrm{ABC}$, that Giant Brokerage will shortly publish a favorable report on $A B C$ probably would be precluded from buying $A B C$ stock until a reasonable time after the report was published. ${ }^{26}$

The hypothetical would have been more difficult if Giant Brokerage Firm had communicated to Mutual Fund its intent shortly to publish a favorable analysis of $\mathrm{ABC}$, including a recommendation to buy. Although Mutual Fund, just like the president of $A B C$, possesses material, non-public information, Mutual Fund did not acquire it as a consequence of a relationship to $\mathrm{ABC}$ which gave it access to the information. ${ }^{27}$

Recent attempts to define the circumstances which trigger a duty to disclose suggest that the relationship test of Cady, Roberts may be too restrictive. In a case decided shortly after Texas Gulf Sulphur, $S E C$ v. Great American Industries, Inc., ${ }^{28}$ three judges in the Court of Appeals for the Second Circuit indicated that they would be willing to extend the duty of affirmative disclosure imposed by rule $10 \mathrm{~b}-5$ beyond the area encompassed by traditional notions of fiduciary responsibility. Great American Industries involved an action by the SEC for an injunction against persons who sold mining properties to Great American in exchange for its shares. The Commission charged that the sellers violated rule $10 \mathrm{~b}-5$ because they failed to disclose a material fact by not telling the buyer that a substantial part of the price paid would be allocated to finders. The majority of the Second Circuit, sitting en banc, held that the facts went considerably beyond

24 Cady, Roberts \& Co., 40 S.E.C. 907, 912 (1961) (footnote omitted).

25401 F.2d at 848.

20 The New York Stock Exchange has disciplined a member of a brokerage firm who, upon hearing from the president of a company that it planned to make a tender offer for its own stock substantially above the market, acquired stock for his wife before the news was made public. SEC, Spectal Study of Securaties Markets, H.R. Doc. No. 95, 88th Cong., 1st Sess., pt. 1, at 435 (1963) [hereinafter cited as Specrar Study].

27 The problems raised by Giant Brokerage Firm's communication of its intent to publish a favorable analysis of $\mathrm{ABC}$ are discussed in detail in notes 127-38 infra \& accompanying text.

28407 F.2d 453 (2d Cir. 1968), cert. denied, 395 U.S. 920 (1969). 
non-disclosure and, therefore, did not think it necessary to determine whether or not a seller might have an affirmative duty of disclosure on the facts presented in that case.

It must be conceded that imposing on sellers of property or finders a duty of full disclosure to a buyer issuing securities in exchange, with a consequent duty on the part of the latter to publicize material facts so disclosed, would increase the protection afforded investors and traders by the securities laws. On the other hand, to read Rule $10 \mathrm{~b}-5$ as placing an affirmative duty of disclosure on persons who in contrast to "insiders" or broker-dealers did not occupy a special relationship to a seller or buyer of securities, would be occupying new ground and would require most careful consideration. ${ }^{29}$

Of the three judges prepared to occupy this "new ground," Judge Kaufman seemed willing to go the furthest. He concluded that, at least for the purpose of granting injunctive relief,

any claim that material facts were withheld in a transaction in connection with the sale or purchase of securities must be scrutinized with care, whether or not there would have been liability at common law for such a deed. ${ }^{30}$

The Kaufman opinion comes close to suggesting that it is inherently unfair for one party to trade with another whom he knows or should know does not possess certain material information.

Although no case has held that there must be parity of material information between the parties to a securities transaction, there is evidence of an SEC disposition to push the law more forcefully in that direction. In Investors Management $\mathrm{Co}_{.}{ }^{31}$ the SEC had its first opportunity to consider whether tippees are subject to prohibitions on trading where they receive material, non-public information about a company. The SEC determined that the prohibitions apply if the tippees "know or have reason to know that [the information] was nonpublic and had been obtained improperly by selective revelation or otherwise."32 This test could be read as prohibiting tippee trading if the tippee knew or had reason to know that the information had been communicated to a small group, regardless of the source of the information. Although a later portion of the opinion states that the information must "[emanate] from a corporate source,"

29 Id. at 460.

30 Id. at 463.

31 SEC Exchange Act Release No. 9267 (July 29, 1971), in [1970-1971 Transfer Binder] CCH FEd. SEC. L. REP. $\| 78,163$.

32 Id. $80,519$.

33 Id. 80,520 . 
of the test stated earlier prompted a special concurrence by Commissioner Smith. He emphasized his belief that the prohibitions of rule $10 \mathrm{~b}-5$ "should continue to be on the conduct of corporate insiders and their privies ... rather than upon a concept ... of relative informational advantages in the market place." ${ }^{34}$ Commissioner Smith would have rephrased the majority's test

in terms of the respondents knowing or having reason to know that the material, non-public information became available to them in breach of a duty owed to the corporation not to disclose or use the information for non-corporate purposes. ${ }^{35}$

The SEC's recent attempts to use rule $10 \mathrm{~b}-5$ to control trading on material non-public market information sharply focus the question whether rule $10 \mathrm{~b}-5$ triggers a duty of disclosure in the absence of an "insider" relationship to the corporation whose securities are affected by the information. Market information is frequently "outside" information-it is generated by sources outside the company whose shares are affected..$^{36}$ The favorable Giant Brokerage Firm analysis and recommendation is one example of outside information. The specialist in ABC stock receives material, non-public information about the flow of trading in the stock from non-company sources. Brokers acquire material, non-public market information in the course

34 Id. $80,523$.

35 Id. 80,523-24 (footnote omitted). Under Commissioner Smith's test the tippee participates in his tippor's breach of duty when he acts on the information received. Commissioner Smith suggested that this analysis may explain the phrase "improperly obtained" in the majority's test.

In the policy statement adopted by Investors Diversified Services, Inc., supra note 21 , in conjunction with the entry of a consent injunction against it, "inside" information is defined as "information that has not been publicly disclosed." Application of that test would impose an equality of information standard. However, the policy statement later limits restrictions on trading to cases where "an IDS employee receives material information about a company which he knows or has reason to believe is directly or indirectly attributable to such company (or its insiders)." Id. at 3 .

The opinion in Crane Co. v. Westinghouse Air Brake Co., 419 F.2d 787 (2d Cir. 1969), cert. denied, 400 U.S. 822 (1972), demonstrates the extent to which a court felt it necessary to find an insider relationship in order to impose a duty to disclose material, non-public information. That case involved competing tender offers for Westinghouse Air Brake by Crane and American Standard. American Standard was a friendly suitor which made its offer following overtures from the management of Air Brake. The Second Circuit concluded that "Standard was an 'insider' with respect to the trading of Air Brake stock." Id. at 796. In support of its conclusion, the court noted that Standard and Air Brake were acting in concert, that Standard informed Air Brake management of Standard's purchases of Air Brake stock, and that Standard was a major stockholder of Air Brake with particular knowledge about its own market purchases. Yet Standard did not receive information as a result of its relationship with Air Brake. Instead, the information relied upon to make Standard an insider was generated by Standard and flowed from Standard to Air Brake. See SEC v. Shapiro, [Current] CCH Fed. SEc. L. ReP. If 93,623 (S.D.N.Y. 1972) (financial consultant concedes that he is insider with respect to merger he seeks to promote).

30 It is possible, although unusual, for corporate information to be generated outside the company whose securities are affected. See 3D ANNOAL INSTITUTE, supra note 6, at 394-97 (discussion of Messrs. Leech, Fleischer, Loomis, Ruder and Mundheim). 
of executing transactions for customers or serving as an outsider's dealer-manager in a tender offer for Target Company stock. Outside information, like inside information, can give one group of market participants an advantage over other participants to whom the information is not available.

The SEC has signaled its growing belief that information disparities, and particularly disparities in market information, must be reduced. In its recent $19 \mathrm{~b}-2$ release the SEC stressed its consistent emphasis on "the removal or limitation of the special trading advantage which any one group or classification of investors holds over another."37 The release then detailed a number of situations in which market information could be used "by professionals to gain a trading advantage over public investors." 38

The disclosure requirements of rule $10 \mathrm{~b}-5$ are an obvious source of power for implementing the theme of "trading fairness" highlighted in the release. Thus, the Chief Counsel of the New York Regional Office of the SEC has concluded that rule $10 \mathrm{~b}-5$ prohibits

the use of any information in the securities marketplace which either should be or is about to be made public, as long as the publication of the information might affect the decision of a reasonable investor. ${ }^{39}$

His view of trading fairness would require placing all buyers and sellers in the market on a parity with respect to the availability of material information. His view of rule 10b-5 would add a new dimension to its role in regulating conduct in connection with the purchase or sale of securities. ${ }^{40}$

The next few years will determine the direction of rule 10b-5's development. The SEC has announced that it is preparing guidelines on the responsibilities and obligations imposed by the rule, including its application to market information. ${ }^{41}$ Further, courts will be required to consider the applicability of rule $10 \mathrm{~b}-5$ to market information. The primary purpose of this article is to make an initial inquiry into the extent to which the rule can appropriately serve as a medium for regulating trading conduct. This inquiry is conducted by analyzing a number of situations in which a purchaser or seller possesses material non-public market information. We conclude that there are substantial limitations in using the antifraud provisions of the federal securities laws to achieve trading fairness.

37 SEC Exchange Act Release No. 9950, at 109 (Jan. 16, 1973).

38 Id. 114-15.

39 Peloso, supra note 14 , at 34 .

40 See notes 67-72 infra \& accompanying text.

41 See N.Y. Times, Feb. 24, 1973, at 37, col. 4-6. 
At the same time we recognize that rule $10 \mathrm{~b}-5$ is not the only basis on which the SEC and the self-regulatory authorities can implement the regulatory goal of trading fairness. For example, our discussion of the regulation of market professionals who occupy key roles in the functioning of the market stresses the complex body of rules designed to ensure fair dealing. These rules, however, are designed to meet broad statutorily-imposed criteria of maintaining "honest and fair markets, ${ }^{242}$ and are not primarily based on the antifraud provisions. Moreover, the SEC can use its power to prescribe the contents of periodic reports and documents such as the registration statement to compel the disclosure of important market information.

\section{Disclosure in the Context of a Corporate AcquistTION PLAN}

Definition of the circumstances requiring affirmative disclosure of material, non-public market information can be approached by examining the duties of various persons who know that a tender offer will shortly be made for a particular stock at a premium over present market price. Assume that Conglomerate Company intends to acquire $51 \%$ of the common stock of Target Company, listed on the New York Stock Exchange, by making a cash tender offer at $\$ 25$ per share, $\$ 5$ above the current market price. Conglomerate presently owns no Target stock and its officers and directors have had no contact with officers or directors of Target. Conglomerate would like to purchase up to $5 \%$ of the outstanding shares of Target stock in the market before announcing its tender offer and making the disclosures required by the Williams Act. $^{43}$ The first question relates

42 See notes 173-75 infra \& accompanying text.

431934 Act $\S 13$ (d) (1), 15 U.S.C. $\$ 78 \mathrm{~m}$ (d) (1), and rule 13d-1, 17 C.F.R. $\S 240.13 \mathrm{~d}-1$ (1972), require any person who has acquired more than $5 \%$ of the stock of a company registered under $\S 12$ of the Act to file a statement with the SEC, the issuer and the exchange on which the stock is listed containing the same type of information required to be furnished by the maker of a tender offer.

Conglomerate's intention to make a tender offer shortly after it has completed its market purchases has been held not to make those purchases part of the tender offer as the term is used in $\S 14(d)(1)$ of the Exchange Act, 15 U.S.C. $\$ 78 \mathrm{n}(\mathrm{d})(1)(1970)$, and thus does not trigger that section's disclosure requirements. Gulf \& Western Industries, Inc. v. Great Atlantic \& Pacific Tea Co., [Current] CCH FED. SEC. L. REP. \{ 93,765 at 93,335, 93,336 (S.D.N.Y., Feb. 13, 1973), aff'd, No. 73-1223 (2d Cir. Mar. 12, 1973). See Wander, Takeovers: Preparing the Attack, in 2D ANndal InSTITUTE on Securrties Regulation 237, 240 (R. Mundheim \& A. Fleischer eds. 1971) [hereinafter cited as 2D ANNUAI INSTITUTE].

Two former staff members of the SEC then charged with interpreting the Williams Bill have contended that market purchases mark the beginning of a "tender offer" under $\S 14(d)$ of the Exchange Act where the person making the purchases has announced his intention to acquire shares of the issuer in an amount that would result in ownership of more than five percent. See Griffin \& Tucker, The Williams Act, Public Law 90-439- 
to Conglomerate's ability to make market purchases without disclosing its plan to make a tender offer at a higher price.

If generally known, Conglomerate's intention to make a tender offer at a $25 \%$ premium over the current NYSE price would be reasonably certain, in terms of probability of occurrence and impact on price, to cause a substantial rise in the price of Target Company stock. Knowledge of the impending tender offer certainly would "affect the desire of [Target shareholders and potential purchasers] to buy, sell, or hold the company's securities," 44 particularly with regard to the timing of purchases or sales of Target stock. Thus, the information is material and non-public. ${ }^{45}$

Nevertheless, it seems clear that under these circumstances Conglomerate has no obligation under rule $10 \mathrm{~b}-5$ (or its Williams Act analogue, section $14(\mathrm{e})$ ) to disclose its plans before making market purchases. ${ }^{46} \mathrm{~A}$ reason for restricting management trading under rule

Growing Pains? 16 How. L.J. 654, 700-01 (1971). The staff of the SEC has also taken the position that, where a company acquired shares of the target through market purchases and through direct solicitation of shareholders for the purpose of acquiring control of the target, these "offers to purchase in the aggregate" constituted a tender offer. See Cattlemen's Investment Co., [1971-1972 Transfer Binder] CCH FED. SEc. I. REP. II 78,775 (Jan. 4, 1972) (interpretative letter).

14 SEC v. Texas Gulf Sulphur Co., 401 F.2d 833, 849 (2d Cir. 1968), cert. denied, 394 U.S. 976 (1969).

45 Although knowledge of the tender offer is market information, knowledge of the potential shift in control of Target Company would be important to an evaluation of the investment worth of Target Company and might thus properly be characterized as corporate information. In addition, if Target Company's assets or earnings are material relative to Conglomerate, information concerning the contemplated takeover would be material corporate information about Conglomerate. See SEC v. Glen Alden Corp., [19671969 Transfer Binder] CCH Fed. SEc. L. Rep. 【 92,280 (S.D.N.Y. 1968).

46 General Time Corp. v. Talley Industries, 403 F.2d 159 (2d Cir. 1968), cert. denied, 393 U.S. 1026 (1969); Jacobsen Mfg. Co. v. Sterling Precision Corp., 282 F. Supp. 598 (E.D. Wis. 1968) ; Pacific Ins. Co. v. Blot, 267 F. Supp. 956 (S.D.N.Y. 1967) (dictum); Mills v. Sarjem Corp., 133 F. Supp. 753 (D.N.J. 1955); A. BroMrerg, supra note 5, \$ 6.3, at 122.5; Fleischer \& Mundheim, Corporate Acquisition by Tender Offer, $115 \mathrm{U}$. PA. L. REv. 317, 328-35 (1967); Note, Cash Tender Offers, 83 HARv. L. REv. 377,389 (1969).

The SEC releases accompanying rule 10b-13 under the Securities Exchange Act of 1934 offer some support for the view that the Commission does not believe rule $10 \mathrm{~b}-5$ is automatically violated if Conglomerate acquires shares in the open market before making a tender offer. Rule $10 \mathrm{~b}-13$ prohibits a person making a tender offer from purchasing securities of the same class other than through the offer during the period of the offer. In the release initially proposing the present form of rule $10 \mathrm{~b}-13$, the Commission stated:

Actual purchases made prior to the inception of that period are not specifically prohibited under the proposed rule, although disclosure of such purchases within a specific prior period is required to be filed in schedules filed under Sections 13(d) and 14(d) of the Act. Such pre-tender purchases, of course, would be subject to the provisions of Rule $10 \mathrm{~b}-5$ under the Act.

SEC Exchange Act Release No. 8595 (May 5, 1969). In the release adopting rule 10b-13

this language was changed as follows:

Purchases made prior to the inception of that period are not specifically prohibited under the rule, although disclosure of such purchases within a specific prior period is required to be filed in schedules filed under Sections 13(d) and 14(d) of the Act. Of course, the general anti-fraud and anti-manipulation provisions could apply to such pre-tender purchases.

SEC Exchange Act Release No. 8712 (Oct. 8, 1969). 
$10 \mathrm{~b}-5$ is to remove any personal interest which management might have in delaying the disclosure of corporate news. ${ }^{47}$ Because Conglomerate is not part of Target management, its purchases of Target stock will not trigger a duty of disclosure on this theory.

A broader basis for restricting securities trading by persons in possession of material undisclosed information is built upon fiduciary responsibility concepts as developed under both state and federal law. ${ }^{48}$ The duty of disclosure seeks to prevent corporate insiders from using information received by virtue of their corporate position to take advantage of investors who are unaware of the information. Conglomerate has no duty of disclosure under this theory because its intention to make a tender offer for Target shares was not obtained through any relationship giving access to Target Company and because it has no fiduciary relationship to Target shareholders which would require disclosure of its plans. Moreover, it would be peculiarly inappropriate to extend rule $10 \mathrm{~b}-5$ to require Conglomerate to disclose its plans to selling Target shareholders. In our case, all relevant facts about Target are public information equally available to Target stockholders. Conglomerate's willingness to make a tender offer at a premium over the market price of Target stock presumably represents its conclusion that Target stock is worth (or potentially is worth) more than the tender offer price. Requiring Conglomerate to disclose its intent to make a tender offer would cause the market price of Target stock to rise, thereby foreclosing its program of market purchases and, in some instances, making the cost of acquiring the necessary shares so great that the tender offer could not be effected. Forcing disclosure under these circumstances might result in the nonoccurrence of the event disclosed, thus depriving Conglomerate of the opportunity to benefit from its superior securities analysis.

If Conglomerate can buy Target stock without disclosing its forthcoming tender offer, can it inform three pension funds about its planned tender offer and urge the funds to establish a position in the stock at the present lower market price? This practice-known as "warehousing"-was considered by the SEC's Institutional Investor Study ${ }^{49}$ in the context of institutional involvement in transfers of corporate control. On the basis of detailed examination of case studies

47 See Mundheim, The Texas Gulf Sulphur Complaint: A Major Step in Restricting Insider Trading in Corporate Securities, 1966 J. Bus. L. 284, 287-89.

48 See text accompanying notes 23-24 supra.

49 SEC, Institutional Investor Study Report, H.R. Doc. No. 92-64, 92d Cong., 1st Sess. (1971) [hereinafter cited as InsTIrotional INvestor Study]. Professor Mundheim served as a consultant to Chapter XV of the Study, parts of which are cited later in this article. 
of transfer situations, the Study found that acquiring companies frequently gave institutions advance notice, in either general or specific terms, of proposed acquisitions. ${ }^{50}$ The Study suggested several reasons for this practice. One purpose of prior disclosure was to develop institutional interest in the acquiring company's stock in order to support the market price of that stock during the period of the offer. ${ }^{51}$ Equally important, however, was the desire of acquiring companies to obtain financing for the tender offer, either by means of a private placement of the acquiring company's securities with the institutions or by encouraging the institutions to establish a position in the target company's stock, with the expectation that the shares purchased would be tendered when the offer was announced. ${ }^{52}$ Another purpose of giving the pension funds early warning of the tender offer might be to make them sympathetic to future calls for help by Conglomerate.

The Study concluded that, to the extent institutional investors had been given non-public information about future acquisitions or non-public earnings projections based on such acquisitions which were material to an evaluation of the acquiring company's stock, institutions might have violated rule $10 \mathrm{~b}-5$ by purchasing the acquiring company's securities without disclosure of that information. ${ }^{53}$ This conclusion seems correct under traditional rule $10 \mathrm{~b}-5$ analysis because the information was received as the result of a relationship giving access to the acquiring company and gave institutions an unfair advantage over persons selling the acquiring company's stock. Conspicuously absent from the Study, however, is any suggestion that institutional purchases of target company stock, based on non-public information received from the acquiring company regarding its planned tender offer, might constitute a violation of rule $10 \mathrm{~b}-5 .{ }^{54}$ Such pur-

505 id. $2773,2828-29,2832-33$.

515 id. 2828-29, 2847.

52 Even though warehousing may be viewed as a form of "financing," this does not necessarily mean that it is an extension of credit and thus subject to the restrictions of the margin requirements. See id. 2836; Lewyn, Financing Takeovers, in 2D ANNOAL INSTITUTE, supra note 43 , at $258,264-65$.

535 InSTITUTIONAI INVESTOR STUDx, supra note 49, at 2830. See SEC v. Glen Alden Corp., [1967-1969 Transfer Binder] CCH FED. Sec. L. ReP. II 92,280 (S.D.N.Y. 1968).

54 The Study concluded that warehousing should be dealt with by new rules rather than under rule 10b-5. [Summary Volume] INSTITUTIONAL INVESTOR STUDY, supra note 49 , at XXXI-XXXIII.

The SEC has rulemaking authority to define and prescribe means reasonably designed to prevent fraudulent practices in connection with tender offers. 1934 Act $\S 14(\mathrm{e})$, 15 U.S.C. \& $78 \mathrm{n}(\mathrm{e})$ (1970). In the hearings preceding the adoption of the amendment to $\$ 14(\mathrm{e})$ granting this rulemaking power, the SEC's Division of Corporation Finance listed, as one of the areas to be covered by rulemaking, the situation in which a "person who has become aware that a tender bid is to be made, or has reason to believe that such bid will be made, may fail to disclose material facts with respect thereto to persons who sell to him securities for which the tender bid is to be made." Hearings on $S$. 336, 
chases would not violate rule $10 \mathrm{~b}-5$ under the Cady, Roberts analysis because the information is received from the acquiring company and the stock traded is that of the Target Company.

There have been suggestions that this analysis is too timid in not finding an antifraud violation in the warehousing of Target Company stock. ${ }^{55}$ Two lines of analysis have been suggested. One line argues that the acquiring corporation's market information is a valuable corporate asset which should not be used for any other person's personal profit. ${ }^{56}$ It assumes that by sharing the information the acquiring corporation is deprived of this asset in connection with a securities transaction and thus has an action under rule $10 \mathrm{~b}-5$ against its directors and the warehousers. ${ }^{57}$ This argument was made in a derivative suit on behalf of an acquiring corporation which had sold target company stock to an institutional investor at the market price, shortly before the acquiring corporation announced a tender offer for target stock at $\$ 17$ above market price. ${ }^{58}$ The court held that, since both the institutional investor and the acquiring corporation knew of the impending tender offer, no deception occurred. It recognized that corporate management had the right to sell corporate assets in an arms-length transaction for consideration (including help in effecting the planned tender offer) which the board thought appropriate. If the board bargained poorly, its judgment could be questioned under state law doctrines of corporate waste and negligent mismanagement. ${ }^{59}$ Indeed, it has been held that an acquiring corporation may enlist the

S. 3431 Before the Subcomm. on Securities of the Senate Comm. on Banking and Currency, 91st Cong., 2d Sess. 12 (1970).

55 See Thomas, Warehousing, 3 REv. SEc. REG. 975 (1970). In addition, Thomas warns that there are a number of other legal problems which may be faced by those engaging in warehousing, including whether the warehousers are "persons" under \$ 13(d) (3) of the 1934 Act, 15 U.S.C. $\$ 78 \mathrm{~m}$ (d) (3) (1970). These problems are outlined in his article. See also 5 Institutional INvestor Study, supro note 49, at 2832-38; Wander, supra note 43 , at $243-45$.

Target may also engage in warehousing. For example, Target may learn that Conglomerate plans a tender offer for its stock. It may seek to oppose the offer by persuading friendly institutions to buy Target stock. Target's ability to inform these institutions poses different problems from Conglomerate's warehousing because Target has a traditional fiduciary duty toward the persons from whom its allies will be purchasing Target stock. Similarly, if Conglomerate advises Target of its impending offer and secures Target's support, Conglomerate may be more restricted than under our original hypothetical in its ability to make market purchases of Target. Conglomerate may be viewed as having received inside information about a material fact, Target's management's support. $C f$. note 45 supra.

56 Wander, supra note 43, at 241; see Kennedy, The Problem in Making a Bid for a New Company, 25 Bus. Law. 853, 856 (1970).

57 See Superintendent of Ins. v. Banker's Life \& Cas. Co., 404 U.S. 6 (1971). The $10 \mathrm{~b}-5$ claim would be in addition to state law claims.

58 Penn Mart Realty Co. v. Becker, 300 F. Supp. 731 (S.D.N.Y. 1969).

59 $C f$. id. at 735-36. That transaction has now been challenged under state law. Penn Mart Realty Co. v. Becker, 298 A.2d 349 (Del. Ch. 1972). 
aid of members of its board of directors by encouraging them to purchase Target Company stock in anticipation of an amalgamation between the two companies. ${ }^{60} \mathrm{~A}$ fortiori Conglomerate should be able to secure the help of the three pension funds with which it deals at arms-length.

It has also been argued that warehousers violate rule $10 \mathrm{~b}-5$ by purchasing Target Company stock without disclosing the market information-the impending tender offer-to sellers of Target Company stock. ${ }^{61}$ In his article on warehousing, Eliot B. Thomas concluded that:

[t]here would be a good deal of merit in a position that as long as the potential acquiring company is acting by itself in acquiring shares of a potential target company, it has no duty to disclose its intention to others, but that once it elects to make known its plans to others, neither they nor the acquiring company may make further purchases without disclosing the acquiring company's intentions. ${ }^{62}$

Although Thomas does not state the reasons for his conclusions, he seems worried about the fairness of enlarging opportunities to take advantage of non-public, material information. Nevertheless, he does not seem to rule out an acquiring company's enhancing its own capacity to buy target company stock by borrowing money. Warehousing can be viewed as an alternative to a bank loan, a public offering of securities, or a private placement as a means of raising the capital necessary to make a tender offer. ${ }^{63}$ Banks frequently are unwilling to finance tender offers without assurance that the target company's revenues will be available as an additional source of funds to service the debt and repay the loan. ${ }^{64}$ Warehousing, thus, may serve an interim financing until it is determined whether sufficient shares have been tendered to give the acquiring company control of the target. Warehousing permits potential acquiring companies who cannot se-

${ }^{60}$ Cohen v. Colvin, 266 F. Supp. 677 (S.D.N.Y. 1967); cf. Bubolz v. Burke, 266 F. Supp. 686 (E.D. Mo. 1967). When the acquiring corporation seeks the assistance of insiders, there is the danger that the call for help was instigated by the desire to benefit the insiders. Arms-length transactions do not present this danger.

In the context of a merger proposal or exchange offer, a purchase of Target Company stock by Conglomerate, its officers or allies could be a violation of rule $10 \mathrm{~b}-6$ under the 1934 Act, 17 C.F.R. \& 240.10b-6 (1972). See Chris-Craft Industries, Inc. v. Bangor Punta Corp., 426 F.2d 569 (2d Cir. 1970); Wheat, Trading Activity in Exchange Offers: Some Possible Pitfalls, in 2D ANNUAL InstixuTe, supra note 43, at 289, 293.

61 Thomas, supra note 55, at 975.

62 Id. 977 .

635 InSTITUTIONAI INVESTOR STUDY, sulpra note 49, at 2828-29, 2836-37, 2848; Sandler \& Conwill, Texas Gulf Sulphur, Reform in the Securities Marketplace, 30 OHro ST. L.J. 225, 254-55 n.145 (1969) (institutions are agents of the offeror and therefore have no greater duty of disclosure than their principal).

645 Institutionat, Investor Study, supra note 49, at 2828. 
cure financing by conventional means to take advantage of their selfgenerated analysis that the target's stock may be underpriced.

More difficult questions are raised where Conglomerate's president secretly buys Target stock for his own account and not to further Conglomerate's business purposes. His purchases normally would be proscribed by state law and he would be liable to Conglomerate for any profit which he made from the purchases. ${ }^{65}$ Because the securities transactions were an integral part of the president's breach of his fiduciary duty to his corporation, he arguably has violated rule $10 \mathrm{~b}-5$ on the basis of the Supreme Court's broad reading of the rule in Superintendent of Insurance v. Bankers' Life \& Casualty $\mathrm{Co}^{68}$ The president's purchases might possibly raise the price of Target Company stock, thereby increasing the cost of Conglomerate's market purchases. His purchases could, therefore, be viewed as operating as a fraud on Conglomerate in connection with its purchases of Target Company stock. This, however, is not a problem of market information; it is a question of the extent to which rule $10 \mathrm{~b}-5$ embraces violations of fiduciary duties in which securities transactions play a part.

The market information issue is presented squarely by the question whether Target stockholders who sold their shares prior to the announcement of Conglomerate's tender offer have a cause of action against Conglomerate's president under rule 10b-5. A remedy is probably not available under state law, because he made no misrepresentations and has no fiduciary relationship to Target stockholders which would require him to make affirmative disclosures. ${ }^{67}$ The same reasons would also argue against $10 \mathrm{~b}-5$ liability to sellers of Target stock. That is, the president has no duty to disclose to them his market information-the contemplated tender offer.

However, as indicated previously, there is a growing inclination to extend the reach of the antifraud rules beyond the area encompassed by traditional corporate fiduciary concepts. The greatest extension would result from the position of those judges in Great American Industries, who thought it might be appropriate to require that a

$65 C f$., e.g., Brophy v. Cities Service Co., 31 Del. Ch. 241, 70 A.2d 5 (1949); Diamond v. Oreamuno, 24 N.Y.2d 494, 248 N.E.2d 910, 301 N.Y.S.2d 78 (1969). Imposition of a prophylactic rule makes it unnecessary to prove that the corporation sustained damages. The court in Diamond suggested that officer's trading on non-public information about a sharp earnings decline might harm the corporation's reputation of integrity, its image, its stockholder relations and public regard for its securities generally. $I d$. at 499,248 N.E.2d at $912-13,301$ N.Y.S.2d at 82.

60404 U.S. 6 (1971) ; see New Park Mining Co. v. Cranmer, 225 F. Supp. 261 (S.D. N.Y. 1963).

67 See, e.g., Azalea Meats, Inc. v. Muscat, 246 F. Supp. 780 (S.D. Fla. 1965), rev'd 208 F.2d 716 (5th Cir. 1967). 
seller in an arms-length transaction disclose the portion of the purchase price that would be paid to the finders. ${ }^{68}$ Imposition of a duty to disclose under those circumstances goes far in the direction of requiring acceptance of the principle that parties to a transaction must, under all circumstances, inform each other of all material facts which they know or should know are not known by the other party and are not publicly available. This principle significantly departs from an underlying assumption of a competitive economy that it is desirable, on the whole, to reward the diligent who have acquired a superior market position. ${ }^{69}$ In terms of legal theory, this departure embodies a dramatic stretching of present doctrine which imposes disclosure obligations upon persons such as agents or trustees, who expressly assume them, or upon persons whose role or relationship to others, such as a seller of products or advice, permits an implication of certain responsibilities. The parity of information principle would require no relationship whatsoever between the parties.

An inflexible principle requiring parity of material market information could be modified by requiring a balancing of this objective with other policy goals. The SEC's reference to "trading fairness"70 might be viewed as embracing this type of alteration of the parity principle. This fairness approach would permit the user of material, non-public information to show that his exploitation of that information represented a legitimate reward for economic effort by him or the person who provided him the information.

Analytically such a fairness approach reflects an attempt to balance at least two considerations which are central to the regulation of securities markets. The securities laws seek to foster public investment by promoting confidence in the securities markets. Elimination of disparities in information available to participants in the trading markets has been an important part of the program to maintain public confidence. At the same time, the federal securities laws also seek to enhance the efficiency of the securities markets as an allocator of resources. Prompt disclosure is important to that aim. In addition,

68 See text accompanying notes 28-30 supra. In Birdman v. Electro-Catheter Corp., [Current] CCH FED. SEC. L. REP. I] 93,934 (E.D. Pa., Jan. 18, 1973), the district court refused to enter summary judgment against a plaintiff alleging that a company violated rule $10 \mathrm{~b}-5$ and $\S 11$ of the 1933 Act, 15 U.S.C. $\$ 77 \mathrm{k}$ (1970), by failing to disclose the potential market impact of the contemplated sale of restricted securities shortly after a public offering by the issuer. Certain statements of the district court in Birdman come close to adopting a parity of information theory. The district court stated: "The omission of such information, if material, would thwart the basic policy of Rule $10 \mathrm{~b}-5$ and to a lesser extent, Section 11 of the Securities Act of 1933 which is that all investors have relatively equal access to material information." [Current] CCH FED. SEC. L. REP. at $93,725-26$.

69 Fleischer \& Mundheim, supra note 46, at 331.

70 See text accompanying note 37 supra. 
sufficient incentives must exist to encourage the digging out of information and careful and imaginative analyses of the available information.

This suggested version of the fairness approach would permit Conglomerate to make market purchases prior to the announcement of its tender offer. It would not prohibit the pension funds' purchases or the purchases of any person whom Conglomerate intended should personally benefit from advance knowledge of the proposed tender offer. On the other hand, the interests being balanced under this fairness approach probably would lead to the conclusion that the president's trading, without the consent of Conglomerate, cannot be justified. His trading lowers confidence in the fairness of the securities markets; prohibition of his trading would not affect the incentives to dig out information or analyze it. ${ }^{71}$

Adoption of this concept of the fairness approach would, however, create substantial difficulties. It imposes on the imprecise standard of materiality the further imprecise test of whether, under the particular circumstances, it is fair for the investor to trade on the basis of the superior knowledge he possesses. This type of vague guideline for appropriate conduct applicable to all participants in the market, including investors, could place undesirable inhibitions on investor trading. Moreover, the fairness approach easily blurs into acceptance of a requirement of parity of information between participants in market transactions.

In any event, adoption of the fairness approach would represent a significant departure from the assumptions underlying present regulation of market activities under rule $10 \mathrm{~b}-5$. The starting assumption today is that market participants have a right to exploit informational advantages. The antifraud concept embodied in rule $10 \mathrm{~b}-5$ limits that right by identifying certain classes of persons who are barred from using certain information for their own benefit. Basically these classes are characterized by relationships to other persons or entities from which it is reasonable to imply an expectation that a person will forego informational advantages which others would be free to exploit. Such restrictions have been consistently applied under rule $10 \mathrm{~b}-5$ to trading by corporate management. ${ }^{2}$

71 The fairness approach would require a person who has material non-public information to disclose it prior to trading in cases where he received the information for a particular purpose but is using it for a different purpose. That limited extension of the prohibitions on trading would not seem to deprive either the giver or the recipient of the information of any legitimate reward for economic effort.

72 In an early $10 \mathrm{~b}-5$ case, Judge Leahy sought to explain the scope and purpose of the rule:

The duty of disclosure stems from the necessity of preventing a corporate insider 
In the course of their work these corporate insiders continuously receive information important to an evaluation of their company's stock. Common law notions developed in the special circumstances doctrine have long indicated that it is inconsistent with their role for corporate officials to use such information to benefit their trading in the corporation's stock. ${ }^{73}$ Corporate officials receive specified compensation from the corporation and are expected not to augment that compensation by taking advantage of shareholders or prospective shareholders through market trading. ${ }^{74}$ Further, compensating management by permitting it to trade on material, inside information would, as Professor Schotland has described, create undue risk of harm to the corporation and to the market. ${ }^{75}$ Rule $10 \mathrm{~b}-5$ builds upon the special circumstances doctrine and has gradually expanded the group of persons who are viewed as corporate insiders and included tippees of insiders as also subject to the trading prohibitions of rule $10 \mathrm{~b}-5 .^{76}$

The relationship of investment advisers to their clients and brokerdealers to their customers has also justified the imposition of trading restrictions under antifraud rules. The implication of restrictions under these circumstances is made easier by the existence of agency relationships which carry with them various common law obligations and by the existence of special statutory sections. governing the conduct of

from utilizing his position to take unfair advantage of the uninformed minority stockholders. It is an attempt to provide some degree of equalization of bargaining position in order that the minority may exercise an informed judgment in any such transaction. Some courts have called this a fiduciary duty while others state it is a duty imposed by the "special circumstances." One of the primary purposes of the Securities Exchange Act of $1934 \ldots$ was to outlaw the use of inside information by corporate officers and principal stockholders for their own financial advantage to the detriment of uninformed public security holders.

Speed v. Transamerica Corp., 99 F. Supp. 808, 829 (D. Del. 1951). This statement is frequently echoed in current opinions. E.g., Radiation Dynamics, Inc. v. Goldmuntz, 464 F.2d 876, 890 (2d Cir. 1972) ("The essential purpose of Rule 10b-5 as we have stated time and again, is to prevent corporate insiders and their tippees from taking unfair advantage of the uninformed outsiders.").

${ }^{73}$ See 3 L. Loss, supra note 23 , at 1446-48. Tentative Draft No. 2 of the ALI's Federal Securities Code crystallizes the "status" concept by taking the position that directors and officers of a company may not trade on the basis of material, non-public information about the corporation no matter what the source of that information. See ALI Fed. Securities Code § 1303 (Tent. Draft No. 2, 1973). Cf. 3D AnNual Institute, supra note 6, at 394-97.

74 Professor Manne argues that the ability to trade on material, non-public corporate information provides a necessary incentive to stimulate entrepreneurial activity within the large, publicly held corporation. H. MANNE, INSIDER TrADING AND THE STOCE MAREET 138-41 (1966). Manne's views did not persuade many of his reviewers.

75 See Schotland, supra note 22 , at 1448-52.

76 See 3 L. Loss, supra note 23 , at $1450-53 ; 6$ id. at 3559-71. The extension of rule $10 \mathrm{~b}-5$ restrictions to tippees of corporate insiders can best be justified on the theory that they are participating in the insider's breach of his fiduciary duty. See notes 31-35 supra \& accompanying text. 
these market professionals. ${ }^{77} \mathrm{~A}$ conceptual basis for developing brokerdealer responsibilities to their customers (irrespective of whether the broker-dealer acted as principal or agent in a particular transaction) has been the shingle theory, which holds that by doing business with the public a "broker-dealer impliedly represents that he will deal fairly with his customers in accordance with the standards of the profession."78 The content of these representations has been developed over time through adjudication and rule making. The shingle theory does not require that a securities firm act as a fiduciary in all dealings with its customers or towards the marketplace. It normally imposes special responsibilities when the firm has placed itself in a position of "trust and confidence" with the customer and it is reasonable to assume a significant degree of reliance by the customer on the firm, regardless of whether the firm acts as agent or deals with the customer as dealer. ${ }^{79}$ In addition, the emphasis in the shingle theory is on a duty to customers, not to the marketplace.

Market information situations raise the question whether the restrictions imposed under the antifraud rules as a consequence of special relationships between persons (or identifiable entities) can be extended to other groups because of their relationship to the functioning of the market. In Affiliated Ute Citizens v. United States, ${ }^{80}$ the Supreme Court seemed to suggest that they could. In that case, two employees of a bank, serving as transfer agent for a corporation holding assets of a group of mixed blood Ute Indians, sought to buy stock in the corporation from its Indian shareholders at a price lower than the price at which the stock was trading among non-Indians. The Supreme Court stated that there would have been no duty to inform the sellers that the stock was selling at a higher price in another market if the bank acted merely as transfer agent for the stock.

771934 Act $\S 15(c), 15$ U.S.C. $\S 780$ (c) (1970); Investment Advisers Act of 1940 $\S 206,15$ U.S.C. $\$ 80 \mathrm{~b}-6$ (1970).

78 Cohen \& Rabin, Broker-Dealer Selling Practice Standards: The Importance of Administrative Adjudication in Their Development, 29 LAw \& ContenrP. Pros. 691, 702, 703 (1964).

70 "The shingle theory, with its implied representation of fairness to a customer, automatically applies to a brokerage firm acting as a broker, and may apply when the firm acts as a dealer, depending on the facts of the case." Jacobs, The Impact of Securities Exchange Act Rule 10b-5 on Broker-Dealers, 57 CoRNeLL L. Rev. 869, 877 (1972). See 3 I. Loss, supra note 23 , at 1482-93, 1500-08.

Under the shingle theory it is regarded as a fraud for a dealer to sell securities to a customer at a price not reasonably related to the current market. See, e.g., SEC v. Charles A. Morris \& Associates, Inc., CCH FED. SEC. L. REP. 爪ी 93,756 (W.D. Tenn. Feb. 1, 1973) ("The failure to inform the customers that the bonds were sold at prices greatly in excess of the then current market prices constituted an omission to disclose a material fact within the meaning of $\$ 17$ (a) and Rule 10b-5.").

80406 U.S. 128 (1972). 
However, the Court found that the employees (and hence the bank) functioned as "market makers" in the stock, encouraged the existence of a separate market in the stock for non-Indians, and allowed the mixed blood sellers to consider them "to be familiar with the market for the shares of stock and rel[y] upon them when they desired to sell their shares." 81 Under these circumstances, reliance by the sellers created a duty to them.

The readiness of the Supreme Court in Ute to infer expectations may perhaps be explained by the apparently unsophisticated nature of the customers who were encouraged to rely on the bank. In this sense, Ute may be interpreted as falling within the ambit of the trust and confidence doctrine in which a non-professional has actively assumed a professional market role. A similar result might occur where the depositary in a tender offer uses information concerning the amount of stock tendered to buy or sell stock of the target company. The depositary, usually a bank, acts as agent for the acquiring company by accepting tendered shares and, subject to the conditions of the offer, holding them until the success of the offer has been determined. Because the bank knows how many Target Company shares have been tendered, it can assess both the likelihood that the offer will succeed and whether shares that are tendered will be taken up in whole or in part. ${ }^{82}$ This information gives the depositary bank trading advantages over Target Company stockholders and arbitrageurs. For example, if the minimum number of shares sought has been deposited irrevocably and all shares tendered will be taken up, the depositary bank can tender Target shares it holds and can purchase additional shares in the market and tender them in riskless transactions. ${ }^{83}$ If the depositary owns Target shares, it may use the information to sell the stock before the failure of the offer becomes publicly apparent. ${ }^{84}$

81 Id. at 152-53.

$82 \mathrm{An}$ offeror typically will condition its obligation to purchase the shares tendered upon the receipt of a specified minimum number of shares, reserving an option to take up as many shares tendered over that minimum as the offeror desires. Fleischer \& Mundheim, supra note 46 , at 336 . Information about the likelihood that the tender offer will succeed has been described as the most important information which target shareholders need in order to determine whether or not to tender their shares. Henry, Activities of Arbitrageurs in Tender Offers, 119 U. PA. L. REv. 466 \& n.3 (1971); see 2D ANNUAT INSTITUTE, supra note 43, at 285-87; Brudney, A Note on Chilling Tender Solicitations, 21 RUTGERS L. REv. 609, 615 n.15, 617-18 (1967); see generally 5 INSTITUTIONAI INVESTOR STUDY, supra note 49, at 2827-49.

83 If the tendered shares are to be taken up pro rata, the calculations which determine whether the bank can trade profitably are different. See Henry, supra note 82, at 469.

84 This permits the bank to take advantage of the price increase caused by the tender offer and to avoid having its shares immobilized until after the close of the offer, at which time the price of Target stock may well have fallen.

The exchange specialist in the securities of Target Company also may be aware of the likelihood of success of the tender offer as the result of trading activity in Target 
Although the depositary's use of the information it acquires about the amount of Target shares tendered can benefit it or its clients, the depositary's purchases or sales of Target stock will usually not harm the maker of the tender offer. The tender offeror generally does not care whose shares it buys pursuant to the offer. Moreover, it is foreclosed by rule 10b-13 from making any market purchases of Target Company stock during the pendency of the offer. Thus, it might be hard to argue that the depositary's market transactions operated as a deceit on the offeror.

Nevertheless, it may be appropriate to bar the depositary from using for its own purposes information it received as a result of the special position in which it was placed by the offeror. Every person tendering Target stock is forced to give that information to the depositary. It would be unfair to permit the depositary to use that information to gain trading advantages over the class of investors who were forced to supply it with the information. ${ }^{85}$

An SEC administrative opinion in a case disciplining a broker may lend some support to this analysis. In that case, ${ }^{86}$ Blyth \& Co. allegedly obtained non-public information about the terms of new government financings from an employee of the Federal Reserve Bank of Philadelphia, who had received the information from the Treasury on a confidential basis. The terms of new offerings affect the market price of existing government securities, particularly when the terms of the new issues differ materially from those expected by government bond traders and other persons interested in this segment of the securities market. Blyth used this non-public market information to effect transactions for its own account in outstanding government

securities. Note, The Downstairs Insider: The Specialist and Rule 10b-5, 42 N.X.U.L. REv. 695, 696, 708-10 (1967). In order to prevent the specialist from taking advantage of this information, the American Stock Exchange provides that the specialist may tender only that number of shares which he held at the time that the tender offer was announced, although in certain instances the Exchange may authorize the specialist to tender a greater number of shares. ASE Rule 187(2) (a) (Commentary), 2 CCH Asr. STOCK EXCE. GUDDE II 9327 (1965) [hereinafter cited as ASE GUIDE]. The foregoing limitations apply only to the specialist's off-floor transactions and would not restrict his use of such information in market trading, although the specialist presumably would be bound by his obligation to trade only in order to maintain a "fair and orderly market." See text accompanying notes 178-94 infra.

85 Compare this situation with an early SEC case, In re Herbert L. Honohan, 13 S.E.C. 754 (1943). In that case Honohan obtained non-public information about bids submitted by bondholders in tenders for a bond sinking fund from an employee of the corporate trustee administering the fund. On the basis of this information, Honohan purchased bonds in the market and tendered them at the highest price at which they would be accepted. The SEC held that Honohan's sales of bonds to the sinking funds operated as a fraud on other bondholders, presumably because their tenders were not accepted as the result. The Honohan opinion did not consider the defendant's liability to persons from whom he purchased the bonds.

86 In re Blyth \& Co., Inc., SEC Exchange Act Release No. 8499 (Jan. 17, 1969), in [1967-1969 Transfer Binder] CCH FED. SEC. L. REP. 【 77,647. 
securities and the SEC held that by doing so Blyth violated rule 10b-5. On its facts Blyth appears distinguishable from the depositary situation because Blyth received the market information from the "issuer" of the securities in which transactions were effected. The depositary receives its information about Target stock from sources other than Target Company. However, the SEC opinion emphasizes Blyth's knowledge that the information was non-public and the trading advantages accruing to Blyth as the result of that information. This emphasis would be a basis for implying that Blyth would also have violated rule $10 \mathrm{~b}-5$ if it had used the information to trade in corporate bonds whose interest rates would be affected by the change in rates paid by the government. The Treasury's position in the government bond market may be viewed not only as an issuer, but as a primary factor, through setting interest rates and maturities, in the trading market itself. The SEC's opinion reflects a belief that the important market information which the Treasury's special role yields may not be used to secure private trading advantages.

Normally, public expectations that market participants will not exploit informational advantages should be implied cautiously. The concept of a duty to the market and extension of the prohibitions of rule $10 \mathrm{~b}-5$ to persons without any special relationship to the class of persons sought to be protected can essentially rest only on the fairness theory. We have identified certain problems with that concept. ${ }^{87} \mathrm{~A}$ sensible application of the fairness approach requires in each instance a careful examination of the role of the party whose actions are complained of, the nature of the alleged wrongdoing, and the expectations of the aggrieved parties. The fairness approach seems to us compatible with an antifraud concept in situations where there is a clear showing of a course of dealing or holding out between the person on whom the duty is imposed and the person to whom the duty is owed so that an expectation of fair dealing between the two parties is justified. In addition, it may be realistic to expect that a market professional who is given a preferred position in order to fulfill a particular market function will use any confidential information received as a consequence of his position solely to further his assigned role. Further, responsibilities usually should be attached only to identifiable groups, such as brokers or dealers, whose activities can conveniently be policed by the regulatory and self-regulatory authorities. Typically, such groups should be able to structure their compensation in a fashion which permits them to pass on their compliance costs to

${ }^{87}$ See notes $67-72$ supra \& accompanying text. 
the protected class, and which makes it unnecessary for them to view the confidential information that they acquire as a perquisite that can be exploited for personal gain.

This view of where the law might properly move would not result in creating any remedies in favor of Target sellers for the president's breach of a duty to Conglomerate. The president is not a member of an identifiable class of market professionals who play a key market role. He has not engaged in any course of dealing with sellers of Target stock that would justify an expectation of fair dealing between them.

On the other hand, as we have noted, a person's role or function may give rise to this expectation. In United States $v$. Peltz, ${ }^{88}$ an attorney was indicted for conspiring with an employee of the SEC to sell Georgia Pacific stock on the basis of confidential information with respect to proposed SEC litigation against Georgia Pacific. Although two counts of the indictment were based on violations of rule $10 \mathrm{~b}-5$, they related to the attorney's false statement that his sales were long rather than short. The complaint did not contain any count alleging a $10 \mathrm{~b}-5$ violation for trading on material nonpublic information. However, the defendant's use of information supplied by an SEC employee was held to violate a special federal statute making it a felony to conspire "to defraud the United States, or any agency thereof in any manner or for any purpose . ..."89 This statute views the fraud to be on the United States or on the SEC. ${ }^{90}$ Thus, it is similar in concept to the theory that a corporate insider violates a duty to the corporation when he uses for his own benefit information received in his corporate capacity. ${ }^{91}$

Although the defendant's trading on confidential information obtained from SEC sources was not charged as a rule 10b-5 violation, a basis for doing so may exist. The SEC's regulatory activities give it an intimate relationship to the functioning of the securities markets. As part of its regulatory activities the SEC receives a continuous flow of material nonpublic information. It is reasonable to expect that such

88433 F.2d 48 (2d Cir. 1970).

8918 U.S.C. $\$ 371$ (1970). 1934 Act $\S 24($ c), 15 U.S.C. $\$ 78 x(c)$, makes it unlawful for an SEC employee to use for personal benefit any information contained in any application, report or document filed with the Commission which has been granted confidential treatment. This prohibition was apparently not applicable to the facts of Peltz.

90 The court pointed out that this statute would also prohibit the use for personal trading of confidential information received from other federal agencies. In addition, it noted that the statute would proscribe an arrangement with a judge's clerk to secure confidential information with respect to a decision having implications for the stock market. 433 F.2d at 52 n.4. (1969).

01 See Diamond v. Oreamuno, 24 N.Y.2d 494, 301 N.Y.S.2d 78, 248 N.E.2d 910 
information will not be used for the personal advantage of persons who are given preferred access to it. $^{.2}$ In this sense the position of SEC employees and their tippees is analogous to the position of the Treasury officials and their tippees discussed in the Blyth case. ${ }^{93}$

\section{Disclosure of INVESTMent Advice}

This section focuses principally on the responsibilities of the market professional who generates market information. The market information on which we will concentrate is the written research report, market letter or technical analysis which results in specific recommendations to buy or sell one or more securities. For our purposes we assume that the report, letter or analysis represents a perceptive analysis of publicly available facts. Thus, there would be no prohibition against acting on the recommendations made. However, the issuance of the recommendation itself may trigger a price impact, because the report, letter or analysis has a wide following or the stock has a thin market. ${ }^{94}$ Knowledge that the recommendation will be issued shortly is therefore material market information. Anyone in possession of such information can profit by buying (if the recommendation will be favorable) before issuance and selling shortly thereafter.

\section{A. Sources of the Duty to Disclose}

The Supreme Court has considered the legality of a pattern of conduct of a subscription adviser who "[purchased] shares of a security for his own account shortly before recommending that security for long-term investment and then immediately [sold] the shares at a profit upon the rise in the market price following the recommendation." 95 The Court held that the adviser's failure to disclose this practice (called scalping) operated as a fraud or deceit upon its clients or prospective clients within the meaning of the Investment Advisers Act of 1940. The Court reasoned that an adviser who trades on the market effect of his recommendation might be motivated to recommend those securities which would be most susceptible to scalping. The practice thus affects the disinterestedness of the advice. At the very least "an investor seeking the advice of a registered investment

92 The SEC's rules of conduct for its own employees embody that expectation.

${ }^{93}$ See text accompanying note 86 supra.

94 See, e.g., SPECIAI STUdx, supra note 26, pt. 3, at 73-76; Ferber, Short-Run Effects of Stock Market Services on Stock Prices, 13 J. Frn. 83 (1958); Note, Stock Scalping By the Investment Adviser: Fraud or Legitimate Business Practice?, 51 CAL. L. REv. 232, 233-35 (1963).

95 SEC v. Capital Gains Research Bureau, Inc., 375 U.S. 180, 181 (1963). 
adviser must, if the legislative purpose is to be served, be permitted to evaluate such overlapping motivations, through appropriate disclosure ...." ".98

Buying or selling a security in advance of a recommendation, without scalping, may itself be improper. The SEC considered that problem in Kidder, Peabody \& $\mathrm{Co}^{97}$ In that case the manager of Kidder, Peabody's Special Investment Advisory Service allegedly ${ }^{28}$ purchased and sold securities for his own account and accounts of his relatives shortly before executing purchase or sale orders for clients of the Special Service at less favorable prices. There was no allegation that the manager or his relatives sold the stock on the price rise resulting from the purchases of the other clients of the Service. The Commission held that the registrant violated the antifraud provisions of the Investment Advisers Act and the Securities Exchange Act, ${ }^{99}$ because the manager did not disclose the preferred treatment given to his own and his relatives' accounts. The SEC's opinion focused on the attempt by the Investment Advisers Act to eliminate conflicts of interest between the adviser and his clients. By holding itself out as an investment adviser to these clients, Kidder, Peabody encouraged them to believe that they were purchasing a disinterested serviceboth with respect to investment advice and the execution of transactions. ${ }^{100}$ The clients were entitled, at a minimum, to a clear warning of any departure from this standard. ${ }^{101}$

98 Id. at 196.

97 In re Kidder, Peabody \& Co., Inc., SEC Exchange Act Release No. 8426 (Oct. 16, 1968), in [1967-1969 Transfer Binder] CCH FED. SEc. L. REP. If 77,618.

98 Although Kidder, Peabody denied the allegations in the SEC complaint, it agreed to a stipulation of facts solely for the purpose of facilitating an Order of Settlement.

99 Investment Advisers Act of 1940 \& 206, 15 U.S.C. § 80b-6 (1970); 1934 Act $\S \S 10(\mathrm{~b}), 15(\mathrm{c}), 15$ U.S.C. $\S \S 78 \mathrm{j}(\mathrm{b}), 780$ (c) (1970); rules 10b-5, 15c1-2, 17 C.F.R. $\S \S 240.10 \mathrm{~b}-5,240.15 \mathrm{c} 1-2$ (1972).

100 Kidder, Peabody \& Co., SEC Exchange Act Release No. 8426 (Oct. 16, 1968), in [1967-1969 Transfer Binder] CCH FED. SEC. L. REP. If 77,618 at 83,324. Investment of its own money or the money of its favored clients in a recommended stock could be viewed as demonstrating the good faith belief of the adviser in the recommendation. Indeed, the Special Study found that investment ideas generated by research departments in brokerage firms frequently were used to invest for the firm account or the accounts of individual firm members. Speciar STUdy, supra note 26, pt. 3, at 245-48. On the other hand, pre-recommendation purchases create the risk of scalping and may affect the disinterestedness of the advice offered. See Howard \& Perlman, SEC Exchange Act Release No. 8970 (Aug. 31, 1971), in 2 CCH FED. SEC. L. REP. I 22,781.30 (analyst held to violate rule $10 \mathrm{~b}-5$ in making a buy recommendation to his firm without disclosing his purchases of the security recommended).

101 The prohibitions on investment adviser trading are supplemented by requirements that partners, officers and directors of the investment adviser and employees involved in the making or communicating of recommendations file quarterly reports with respect to all of their securities transactions. SEC Investment Adv. Act Rule 204-2(12), 17 C.F.R. \& 275.204-2(12) (1972). In addition to the reports required by rule 204-2(12), many investment advisory complexes enforce policies restricting officer and employee trading by requiring all officers and employees to execute personal securities transactions through an affiliated broker. See, e.g., SEC, PUBLIC PoLICY Implications OF Investarent 
The SEC has recently proposed extending the Kidder, Peabody doctrine, in the case of persons affiliated with investment companies, to bar pre-recommendation purchases. In its Public Policy Implications of Investment Company Growth report, the SEC expressed concern about purchases and sales of securities by persons associated with an investment company on the basis of their knowledge of the company's projected portfolio transactions. ${ }^{102}$ Advance knowledge of recommendations made or to be made by an investment adviser to its investment company clients would present an opportunity for profiting on in and out trading. In addition, purchasing or selling ahead of the investment company might adversely affect the price to the investment company of securities bought or sold. ${ }^{103}$ Congress responded to the SEC's concerns by giving it power to enact rules prohibiting these trading practices. ${ }^{104}$ The SEC has proposed rule $17 \mathrm{j}-1^{105}$ under the Investment Company Act of 1940 which would make it a fraudulent practice for various persons affiliated with an investment company to buy or sell a security which is being considered for purchase or sale, or being purchased or sold, by the investment company..$^{108}$

The concept of proscribing pre-recommendation transactions also applies to brokerage firms. The New York and American Stock Exchanges prohibit member firm personnel with advance knowledge of purchase or sale recommendations from taking action in contemplation of the report, "such as making a transaction for their own account ... or passing on advance information ... to persons outside their firm."107 Even after firm customers are informed of a recommendation, firm personnel may not act "for accounts in which they have an interest,

Company Growte, H.R. Rep. No. 2337, 89th Cong., 2d Sess. 197 (1966) ; Special Study, supra note 26 , pt. 4 , at 246.

102 SEC, Public Policy Implicatrons of Investment Company Growte, H.R. REP. No. 2337, 89th Cong., 2d Sess. 195-200 (1966).

103 The report also points out that an investment company may be harmed if it is induced to manage its portfolio in a way which protects or strengthens the insider's securities position. (1970).

104 Investment Company Amendment Act of $1970 \S 9(\mathrm{c})$, 15 U.S.C. $\S 80 a-17(\mathrm{j})$

10538 Fed. Reg. 2180 (1973).

106 SEC Investment Co. Act Release No. 7581 (Dec. 26, 1972), in [Current Devolopments] CCH FED. SEC. L. REP. If 79,157. The release notes that the rule "proposes a definite anti-fraud proscription against 'insider trading' by access persons with knowledge of the investment company's transactions." Id. 82,519. As one SEC staff member stated: "Thus, there is no question that rules under Section 17(j) may cover transactions based on extrinsic information about the portfolio company rather than intrinsic information about the company's earnings or prospects." Comments of Lewis J. Mendelson, PLI, TrE SEC SPEAKS 43 (1972).

107 New York Stock Exchange, Member Firm Circular No. 170 (Nov. 16, 1962), reprinted in New York Stock Exchange, Guidelines for Member Firm Communications with the Public 5 (1970) [hereinafter cited as NYSE Guidelines]; American Stock EXchange, Info. Circular No. 51-71 (Apr. 30, 1971) (barring pre-recommendation purchases). 
either in accordance with or contrary to the recommendation, until the market effect of the recommendation is spent."10s

Capital Gains and Kidder, Peabody and the rules against prerecommendation trading are directed in substantial part at protecting the professional quality of service rendered by persons offering investment advice. Although disclosure is the regulatory technique applied by the cases, it would normally be so embarrassing or impractical to make the required disclosures that, as a practical matter, in most instances scalping and sneaking to the head of the line can be viewed as prohibited.109 The absolute bar against pre-recommendation transactions contained in proposed rule $17 \mathrm{j}-1$ and the Exchange rules probably reflects a growing belief that disclosure cannot be adequately made and, more importantly, that such transactions are incompatible with professional conduct.

A recent SEC injunctive action appears to attack scalping as creating harm to persons other than those to whom investment advice is offered. In a complaint ${ }^{110}$ filed against the financial columnist of a West Coast newspaper and his son, an editor of a financial journal, the SEC alleged that the two engaged in scalping on the basis of favorable articles about certain companies which appeared in the father's column and in the financial journal. The complaint first charged that rule $10 \mathrm{~b}-5$ was violated because the defendants did not disclose in the columns or otherwise that they had purchased shares in the companies written up prior to the appearance of the columns and that they planned to benefit from the anticipated price rise. This aspect of the complaint tracks the theory of Capital Gains and applies it to a financial columnist, rather than to an investment adviser or broker. Even though a financial columnist appears to be exempted from registration as an investment adviser, ${ }^{111}$ a prohibition under the antifraud provisions of

108 NYSE Guidelines, supra note 107 , at 5 (emphasis added).

109 See O'Boyle, Broker-Dealer Confict of Interest Problems, in 3D ANNUAL INSTITUTE, supra note 6 , at $457,485-86$.

110 SEC v. Campbell, Civ. No. 72-1684-WMD (C.D. Cal., July 24, 1972), in CCH FED. SEC. L. REP. $\uparrow 93,580$. Campbell consented to a temporary injunction pending a final decision in the action. L.A. Times, Nov. 23, 1972, at 19, col. 2.

111 See Investment Advisers Act of 1940 § 202(a)(11), 15 U.S.C. $\S 806-2$ (a)(11) (1970) ; 2 L. Loss, supra note 23, at 1398; Loomis, The Securities Exchange Act of 1934 and the Investment Advisers Act of 1940, 28 GEo. WASE. L. REv. 214, 245 (1959). Loomis states:

This exemption is presumably applicable also to syndicated columnists even if technically they are independent contractors rather than employees of publishers. There is no comparable exemption for radio and television stations and a question may therefore arise as to whether such stations, or producers or programs over them, may not fall within the definition of investment advisers if they broadcast programs of investment advice. The fact that their compensation comes from the sponsor rather than directly from the listeners is not necessarily decisive.

Id. at 245 n.97. 
rule $10 \mathrm{~b}-5$ against his scalping on his own columns may be warranted. ${ }^{112}$ A financial columnist, like an investment adviser, develops a following because of public confidence in the competence and objectivity of his reporting. In addition, like a market professional, he receives preferred access to information-in his case the information is given for the purpose of having it communicated to the public. Moreover, much of this information is received from corporate sources and thus subject to traditional rule $10 \mathrm{~b}-5$ coverage. A number of financial publications appear to have recognized that the public expects financial columnists and business writers to observe certain restraints in their investment activities and have adopted internal standards of conduct governing them. ${ }^{113}$ Finally, section 17 (b) of the 1933 Act, which in effect prohibits the publication of any article about a company without fully disclosing the receipt of any consideration for the publication of the article, provides a helpful analogy. ${ }^{114}$

The second allegation in the Campbell complaint appears to break new ground. The SEC charged that the defendants violated rule 10b-5 by making market purchases of stocks of corporations shortly before the appearance of the newspaper articles about the corporations without disclosing to their sellers that a favorable story would soon appear. Thus, the SEC is contending that the defendants' purchases of stock

112 Arguments that the policies which require disclosure by investment advisers should also apply to journalists are discussed in Peskind, Regulation of the Financial Press: A Nerw Dimension to Section 10(b) and Rule 10b-5, 14 St. Lous L.J. 80, 85-92 (1969) (A financial writer "impliedly warrants that the article is written from a disinterested perspective and that the author intends to gain nothing more from the article than his fee or salary for writing it." Id. 91.); see Leavell, Investment Advice and the Fraud Rules, 65 MICE. L. REv. 1569 (1967); Comment, The Regulation of Investment Advice: Subscription Advisers and Fiduciary Duties, 63 Micr. L. Rev. 1220 (1965); Note, Investment Advisers and Disclosure of an Intent to Trade, 71 YALE L.J. 1342 (1962); see generally SRECIAI STUDY, supra note 26, pt. 3, at 65-102.

113 See Livingston, Code of Ethics Needed for Financial Writers?, Philadelphia Inq., Aug. 27,1972 . at $17-c$, col. 1 (describing the Wall Street Journal's policy statement to its staff members). The Special Study found that the senior editor in charge of the business news section of a major national magazine successfully engaged in scalping on the basis of articles about companies which would be written up in the magazine. In general, the companies written up were small and little known and the editor was able to profit by short-term trading. Special Study, supra note 26, pt. 3, at 73-76. After the employee was dismissed, the magazine distributed a statement of policy which provided in part:

Profiting from special information.

-It has been a long standing point of policy that no employee of [the magazine] should try to profit (by buying or selling securities or otherwise) from special information that one of our magazines plans to carry a story or picture on a company. In the very unusual case of a staff member who holds a significant interest in a company and who might be assigned on a story about that company, his personal interest should be referred to the managing editor or his supervisor in advance.

Id. at 76 n.130.

114 Section 17 (b), 15 U.S.C. $\S 77 q(b)(1970)$, by its terms only applies if the consideration received comes from "an issuer, underwriter or dealer." In the financial columnist case, the special consideration comes from the opportunity to scalp. 
at prices as yet unaffected by the demand to be generated from the articles operated as a fraud or deceit on the sellers, not just on the readers to whom the article was directed. This theory apparently shifts emphasis from concern with providing impartial investment advice and protecting the consumers of that advice to preventing the use of market information to obtain an advantage over those to whom no special duties were explicitly undertaken. The complaint reflects a view that under these circumstances an honest and fair market compels a financial columnist not to trade and that every buyer or seller affected by the columnist's trading has a right of action against him. ${ }^{115}$

The attempt to fashion a widely available remedy may reflect an SEC desire to enlist a larger group to police columnist conduct through private actions. This attempt would try to find an analogy in the insider trading cases. An insider selling stock in the market on confidential corporate information may be liable to any person who bought stock concurrently with or subsequent to the insider's sales and prior to public disclosure of the confidential information. ${ }^{116}$

There are, however, significant differences between the insider trading case and the financial columnist case. Although the insider's responsibilities flow from his relationship to the corporation, his obligation not to profit from confidential corporate information may be met either by not trading or by disclosing the information to the market. If he trades without disclosing the information, the insider harms sellers because they would not have completed the transaction had the confidential information been generally available. ${ }^{117}$ On the other hand, the financial columnist's disclosure responsibilities should be satisfied if the column itself discloses his intent to scalp. Under that analysis, any sellers prior to publication would not be affected by the disclosure. Sellers after publication of the column would obtain any price benefits from the demand generated by the column.

From a pure policing point of view, the corporation in the insider trading case provides the only alternative to buyers as a potential private plaintiff. However, the corporation may not be a buyer during the relevant period and, thus, may not have standing to sue under the Birnbaum test. ${ }^{118}$ In addition, insiders may own a substantial amount

115 For a discussion of possible justifications for such a view, see text accompanying notes 120-23 infra.

116 Shapiro v. Merrill Lynch, Pierce, Fenner \& Smith, Inc., [Current] CCH FED. SEc. L. REP. If 93,714 (S.D.N.Y. 1972).

117 It has been argued that "since the seller would presumably have sold to another buyer even if the insider had fulfilled his duty under the Act by not trading, it cannot be said that the insider's violation of the Act damaged the seller." Note, 80 HARv. L. REv. 468,475 (1966). The Court in Shapiro specifically rejected that argument. [Current] CCH FED. SEC. L. REP., at 93,170-93.

118 Birnbaum v. Newport Steel Corp., 193 F.2d 461 (2d Cir. 1952), cert. denied, 343 
of the corporation's stock and may be able to recover, indirectly, some of the squeezed out profit. Although adjustments in the amount of recovery could be made to reflect the insider's interest in the corporation, these adjustments would frequently present complex problems. On the other hand, the readers to whom the financial column is directed would normally be sufficiently numerous and have adequate incentives to sue to squeeze out any improper profits made by the columnist.

The weakness of the insider trading analogy suggests, therefore, that the second allegation in the Campbell case is intended to go beyond the creation of a remedy, and asserts the existence of a general duty to the market. ${ }^{119}$ As we have previously indicated, the creation of a duty to the market under these circumstances would stretch the concepts of rule $10 \mathrm{~b}-5$ to embrace a broad fairness approach.

This view of the Campbell complaint has potentially troubling implications. Assume Over-the-Counter Retail Firm perceptively analyzes publicly available information about XYZ Corporation, a company with a relatively small amount of common stock available for trading. Retail Firm plans to recommend purchase of XYZ to its customers in a research report which will be mailed to them. May Retail Firm establish a position in XYZ prior to the publication of the report and then sell the stock accumulated to its customers? Must Retail Firm disclose to those persons who sell XYZ to it that it intends subsequently to recommend XYZ? ${ }^{120}$

Retail Firm's purchases presumably will be made at prices lower than sellers would get if they sold after the recommendation is published. In accord with the Campbell complaint, the sellers would argue that Retail Firm had material, non-public market information (the knowledge that it will shortly issue a recommendation) and that its failure to disclose that information to the sellers operated as a fraud or deceit on them. However, Retail Firm's practice, which is not uncommon, can be justified as a legitimate exploitation of its perceptive

U.S. 956 (1952). The doctrine is discussed in Lowenfels, The Demise of the Birnbantm Doctrine: A New Era for Rule 10b-5, 54 VA. L. Rev. 268 (1968). See also 6 L. Loss, supra note 23 , at $3613-45$.

Diamond v. Oreamuno, 24 N.Y.2d 494, 301 N.Y.S.2d 78, 248 N.E.2d 910 (1969), the only case in which a corporation was allowed to squeeze out profit earned as a consequence of trading on inside information, was decided on common law grounds. Counsel for plaintiffs informed one of the authors that the Birnbaum problem prompted avoidance of a rule $10 \mathrm{~b}-5$ claim.

119 As we have indicated, note 106 supra, proposed SEC rule $17 \mathrm{j}-1$ includes an antifraud proscription against insider trading by "access persons" of investment companies who have knowledge of the companies' projected portfolio transactions. This rule could be read as providing protection not only to the investment companies involved, but also to all investors in the market. See Letter of Comment of the Association of the Bar of the City of New York, Feb. 26, 1973 (relating to proposed rule 17j-1).

120 Retail Firm salesmen probably could not solicit customers to sell the stock to Retail Firm at a time when it will shortly recommend the stock for purchase. 
analysis of XYZ. In addition, by careful assembly of an inventory of XYZ which it makes available to its customers, Retail Firm may prevent a temporary imbalance of supply and demand which would cause the price of XYZ to rise too rapidly, thus increasing the price which must be paid by Retail Firm's customers.

Acceptance of the sellers' argument would not only prevent this contribution to a more orderly market, but would force a dealer to choose between capitalizing on his investment ideas either as an investor or as a broker. ${ }^{121}$ Limitations on incentives to develop investment ideas should only be imposed if it is necessary to avoid a harm which would otherwise be created by the incentive. The basic risk in this case is that Retail Firm's purchases will skew its investment judgment by motivating it to recommend stocks which are susceptible to price rises as a consequence of the recommendation. Even in the investment adviser situation, the existence of this type of conflict of interest is not prohibited. ${ }^{122}$ Disclosure is considered the basic regulatory tool. ${ }^{123}$

121 If the price of XYZ climbs too rapidly, XYZ may no longer be a reasonable purchase. At that point Retail Firm cannot earn any commissions for putting its customers into an undervalued situation which it has discovered. It is interesting that \$ $206(3)$ of the Investment Advisers Act, 15 U.S.C. \$ 80b-6(3) (1970), explicitly provides that the prohibitions on acting as a principal in selling securities to a client do not apply "to any transaction with a customer of a broker or dealer if such broker or dealer is not acting as an investment adviser in relation to such transaction."

122 Under $\S 206(3)$ of the Investment Advisers Act, 15 U.S.C. $\S 80 \mathrm{~b}-6(3)$ (1970), an investment adviser may sell securities to, or purchase securities from, a client if he obtains the client's consent to the transaction after fully disclosing any adverse interest he may have. In the view of the staff of the SEC, the disclosure should include the capacity in which the adviser proposes to act; the cost to the adviser of any security which he proposes to sell to his client; and the best price at which the transaction could be effected by or for the client elsewhere if such price is more advantageous to the client than the actual purchase or sale price. SEC Investment Adv. Act Release No. 1A-40 (Jan. 5, 1945), in 3 CCH FEd. SEC. L. REP. Tf 56,375.

123 In Chasins v. Smith, Barney \& Co., 438 F.2d 1167 (2d Cir. 1971), a firm which evaluated a customer's portfolio and strongly recommended sale of some of the customer's holdings and purchase of three stocks in which the firm was making a market was held to have violated rule $10 \mathrm{~b}-5$ by failing to disclose its position as a market maker of the recommended stocks. The court reasoned that the firm's investment judgment might be tainted by its inventory position and that the customer "must be permitted to evaluate overlapping motivations through appropriate disclosures, especially where one motivation is economic self-interest." Id. at 1172 .

Judge Friendly, joined by Chief Judge Lumbard and Judge Moore, wrote a strong dissent to the refusal of the Second Circuit to hear the case en banc. Judge Friendly argued that under the circumstances the imposition of a duty to make the disclosures contemplated by the opinion could only be accomplished by administrative action with prosective application. Cf. Batchelor v. Legg \& Co., CCH FED. SEC. L. REP. 『 93,120 (D. Md. 1971) (market maker need not specifically indicate that it was acting as such where it was not giving investment advice to customer).

One of the persistent questions under the antifraud rules is whether fraud can ever exist where full disclosure is made to a person able to understand the information communicated. Capital Gains and Kidder, Peabody were both decided on the ground that adequate disclosure had not been made. Although the SEC staff recently has characterized certain transactions as "inherently fraudulent," see, e.g., Argus Securities Management Corporation, [1971-1972 Transfer Binder] CCH FED. SEC. L. REP. II 78,366 (1971), the SEC itself has been very cautious about taking such a position. See SEC, REPORT OF

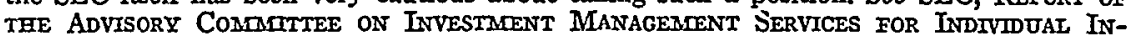
vestors, Sarali Account Investarent Management Services 40-42 (1973). 
It would be peculiarly inappropriate to go beyond this approach in the case of Retail Firm.

Dealers such as Retail Firm are generally recognized as subject to conflicts of interest in rendering investment advice. Customers are informed that they are dealing with the firm as principal. Moreover, the compensation structure in the industry results in a broker-dealer being compensated only if there is activity in a customer's account and rewards him differently for the sale of different securities and for the sale of the same securities in different situations. ${ }^{124}$ Since the primary regulatory technique for dealing with these conflicts of interest is disclosure, it would be necessary for Retail Firm to tell its customers that it had purchased XYZ stock prior to releasing the recommendation. ${ }^{125}$ The SEC has been unwilling to deal more radically with existing conflicts in the broker-dealer sector. It has rejected separating brokerdealer functions or, at the retail level, forcing a divorce between the execution and advisory functions. ${ }^{126}$ At the same time regulation by disclosure has been supplemented through the imposition on brokerdealers of fiduciary responsibilities toward their customers, and by limiting broker-dealers to recommendations which have a reasonable basis and are suitable for the customers to whom the recommendations are made.

Under these circumstances, sellers who sue Retail Firm must go beyond even the fairness approach which is needed to support the second allegation of the SEC's Campbell complaint and rely on the principle of parity of information. We have previously indicated our view that rule $10 \mathrm{~b}-5$ would not support application of this principle.

Even if it is clear that Retail Firm can purchase XYZ stock for its own account prior to publication of its favorable recommendation,

\footnotetext{
124 For a discussion of compensation in the securities industry, see Ratner, Regulation of the Compensation of Securities Dealers, 55 CoRnerr L.Q. 348 (1970).

125 See O'Boyle, Broker-Dealer Conflict of Interest Problems, in 3D ANNuar InsTITUTE, supra note 6 , at 457,482 ; compare Chasins v. Smith, Barney \& Co., 438 F.2d 1167 (2d Cir. 1971), with SEC v. R.A. Holman \& Co., 366 F.2d 456 (2d Cir. 1966). O'Boyle suggests that, even though the purpose of such an inventory build-up may be to enable the customer to obtain the security at a reasonable price, it would seem advisable to explain to customers what has actually been done, including possible disclosure of the price range and time period of the build-up. If the firm, on the other hand, is liquidating an "investment" position or a position acquired as underwriter's compensation, specific disclosure of these facts (and probably of the reasons for the liquidation) should be made if the firm desires to recommend the security to its public customers. O'Boyle also points out that a broker accumulating a block immediately before recommending the security to customers may have problems under 1934 Act Rule 10b-6, 17 C.F.R. \& 240.10b-6 (1972). See O'Boyle, Distributions and Rule 10b-6 Underwritings, in 2D ANNUAL INSTITUTE, supra note 43, at 125, 129-31.

126 See 2 L. Loss, supra note 23, at 1215-18; 5 id. 3242 (segregation of brokerdealer functions); SEC Statement on the Future Structure of the Securities Markets (Feb. 2, 1972), in 137 BNA SEC. Reg. \& L. ReP. pt. II, at 6-7 (divorce between execution and advisory functions).
} 
somewhat different questions appear to be raised where Retail Firm advises a select group of its customers to buy XYZ before a recommendation is released to the rest of Retail Firm's customers. ${ }^{127}$ That practice was successfully attacked in Courtland $v$. Walston \& $\mathrm{Co}^{128}$ In that case the officer in charge of the investment advisory service of Walston \& Co. followed a pattern of giving certain customers advance notice of recommendations which would appear in a weekly market letter so that those customers could establish positions in the recommended stocks. The court assumed that the market letters contained honest, reasonably based advice. The plaintiff in this case was one of the preferred customers who sued when the stocks she claimed she was induced to buy by the grant of material market information depreciated in value. The court held that the practice operated as a fraud upon the plaintiff:

It had as its purpose, effective in the case of the plaintiff, to induce the sale of securities which she owned, through defendants, and the purchase of securities recommended by defendants. This, of course, generated a trading volume, and produced brokers' commissions beneficial both to the registered representatives advising plaintiff and to Walston. Use of this device, without more, gives rise to liability, although it is satisfactorily established that the securities recommended were considered "good" recommendations, and that the sales recommendations [were reasonably justified]. ${ }^{129}$

More importantly for our purposes, the court seemed to imply that the practice of alerting certain customers to the stocks which would be recommended also operated as a fraud on persons who sold the stock without knowledge of the forthcoming letter. The court stated:

She [plaintiff] knew, or must be deemed to have known, that if she received recommendations prior to the publication of the market letter, and bought the stocks recommended, she would be taking advantage of sellers who would be selling the stocks without benefit of such special knowledge and who, if the market letter pushed up the stock, would be financial losers to that extent. ${ }^{130}$

The court's analysis seems to reflect views similar to those underlying the Campbell allegations that the financial columnist who scalped

127 If Retail Firm itself were prohibited from purchasing XYZ stock prior to publication of its recommendation, it would normally also be prohibited from alerting anyone to its forthcoming recommendation. Any person purchasing stock on the basis of such a tip would probably be considered a participant in Retail Firm's securities law violation.

128340 F. Supp. 1076 (S.D.N.Y. 1972).

$129 I d$. at 1082 .

$180 I d$, at 1084 (emphasis added). 
on his newspaper columns violated a duty of disclosure under rule $10 \mathrm{~b}-5$ to sellers of the stocks discussed. ${ }^{131}$ The court did not explain why rule $10 \mathrm{~b}-5$ should be stretched to grant protection to the sellers. The harm they suffer is no different from the harm which occurs whenever an investor sells stock shortly before the issuance of an influential brokerage firm's buy recommendation.

Any analysis of the court's opinion must recognize that the court did not directly address itself to the question of whether the broker violated rule $10 \mathrm{~b}-5$ with respect to the sellers who sold before publication of the letter. The court seemed to be most concerned about the broker's permitting customers to scalp his recommendations. The court probably believed that sellers prior to the recommendation and purchasers after the recommendation should be given rights of action as a way of helping police the broker's conduct. ${ }^{132}$ Indeed, the court permitted the customer who "intentionally" took advantage of the broker's "scheme" to recover from the broker because of the salutary policing effect. Moreover, the court's analysis is in large part directed to the potential scalping problem inherent in advance tipping of market letters. The court quoted at length from an SEC complaint ${ }^{133}$ in which an investment adviser followed a pattern of communicating recommendations to three classes of clients at three different times. The adviser would first purchase the securities for discretionary accounts and then sell the securities in the discretionary accounts while recommending them to the other clients. The court relied on Loss, Securities Regulation, for support that the allegations in the complaint constituted a manipulative or deceptive device..$^{134}$ It is interesting that Loss views that complaint as illustrating the SEC's view that "an investment adviser must avoid conflicts between himself and his clients or between different classes of clients." ${ }^{\text {"135 }} \mathrm{He}$ stresses fraud on clients, not on sellers.

The impact of the court's decision in Courtland may also be limited because of the court's finding that an investment advisory relationship existed between the plaintiff and Walston and that the defendants' conduct violated the Investment Advisers Act. Viewed as an example of a private action designed to help protect the quality of investment advice, the case does not present much of an advance over Capital Gains or Kidder, Peabody. Finally, the Courtland court stressed that the market letter did not present analyses of companies but was written

131 See text accompanying notes $110-14$ supra.

132340 F. Supp. at 1085. See text accompanying notes 116-19 supra.

133 SEC v. Todd, Civil No. 6149 (D. Mass. 1946).

134340 F. Supp. at 1084, citing 3 L. Loss, supra note 23, at 1516.

1353 L. Loss, supra note 23, at 1516 (footnote omitted). 
from the point of view of a market analyst, "who discerned trends with respect to the public favor or disfavor of securities in particular industries and of particular companies, and also the supply and demand of securities." ${ }^{136}$ Such a letter is directed, in substantial part, toward short-term trading and thus provides a strong inducement to favored customers to take advantage of the short-term impact of the letter by trading on its release. Indeed, the vice of the tipping practice in connection with this kind of market letter is that it gives a systematic advantage to one group of the firm's customers at the expense of another group of the firm's customers.

Despite these potential limits on the reach of the Courtland opinion, it is doubtful that a broker-dealer can exploit knowledge of a forthcoming recommendation, whether technical or fundamental in nature, by tipping certain customers to the fact it will shortly be issued. It may well be assumed that, at least, certain customers will scalp on the recommendation when it is made publicly available. With the exception of the Retail Firm type of situation described earlier, a person dispensing investment advice may not scalp, and may not pass along the opportunity to favored customers. ${ }^{137}$ Scalping has not been shown to produce economic benefits or make the securities markets more efficient; on the contrary, it raises questions relating to the quality of the services being offered. It is perhaps for these reasons that the NYSE prohibits passing on advance information concerning a recommendation to favored customers. ${ }^{138}$

\section{B. Availability of Recommendations}

Prohibiting investment advisers and broker-dealers from tipping favored customers to the existence of a forthcoming recommendation does not necessarily mean that investment advisers and broker-dealers violate the antifraud rules or self-regulatory guidelines because their research recommendations are not simultaneously made available to all their clients. Their clients vary greatly: discretionary accounts; those who purchase advice for a fee; large, active institutional accounts; less active institutional accounts; smaller, public accounts with broad ranges of activity.

When a firm decides to recommend a security, it usually cannot do so in a way which permits all its customers an equal opportunity to

136340 F. Supp. at 1084.

${ }^{137}$ Irving Pollack, the Director of the SEC's Division of Securities Markets Enforcement advised "broker[s] not [to] use any pattern of conduct or any course of business which will provide somebody the opportunity to scalp him or to take advantage of him." 3D ANNOAI INSTITUTE, supra note 6, at 313.

138 See note 107 supra \& accompanying text. 
react to the recommendation. For a large firm it will be impossible to make simultaneous telephone calls. Mail arrives, if at all, at different and unpredictable times. Further, any rule requiring an equal opportunity to react could discriminate against discretionary accounts. Trading in these accounts would have to be delayed for an arbitrary period which, as a practical matter, could commence only after some of the firm's other clients had already reacted to the recommendation. Under present NYSE guidelines, brokers are free to act for discretionary accounts at the same time that customers generally learn of the recommendation..$^{139}$

A rule requiring dissemination in equivalent ways would, for most firms, result in mail notification. Firms with only a limited number of large clients would then obtain a competitive advantage by the practice of notifying all their clients by telephone. Present practice may often involve an attempt to communicate recommendations within the firm and then to authorize simultaneous release to customers. Notification of customers will occur in a number of different ways. Institutions and other important clients who may be interested in the security are called on the telephone and the recommendation and underlying report are discussed with them. Many clients will be informed by mail. And some clients may not be informed of the recommendation at all..$^{140}$

This procedure, which can operate to give effect to the relative economic importance of various clients to particular registered representatives and to the firm, appears to accord generally with customer expectations. ${ }^{141}$ There have been suggestions which encourage brokerdealers and investment advisers to describe to their customers the process of information dissemination, including fairly specific under-

139 NYSE Guidelines, supra note 107, at 5; American Stock Exchange, Info. Circular No. 51-71 (Apr. 30, 1971). At least one NXSE member firm states it gives its discretionary clients "the full, first benefit of the firm's research recommendations." SANFORD C. Bernstenn \& Co., Policy and Procedures Manual 4 (1972) [hereinafter cited as BERNSTERT].

140 Existing studies of practices in allocating advice among clients of brokers and investment advisers suggest the absence of uniform standards. See SPECIAI STUDX, supra note 26, pt. 1, at 373-74; 2 INSTITUTIONAI INVESTOR STUDY, supra note 49 at 348-55, 372-74. See also PLI, Institurional Investors in a Changeng Economy 14-17, 37-40, 223-26, 244-45, 333-34 (1970).

141 See Henderson, Conficts of Interest for the Money Manager, in 3D ANnuad IvSTITUTE, supra note 6, at 293, 299, 306-14. But see Interview with Philip Loomis, Jr., Gen'l. Counsel, SEC, at the Fall Conference of the Financial Analysts Federation (1968) (reprints available from the Financial Analysts Federation). For an example of the allocation practices of one New York Stock Exchange firm, see BERNSTEIN, supra note 139. Cf. PLI, Institutional Investors in a Changing Economiy 223-26 (1971) (remarks of Peter Bernstein).

General customer expectations are irrelevant where specific representations about a firm's policy have been made to the customer by the firm or its salesmen. Moreover, general customer expectations do not remain constant. Statements by the regulatory or self-regulatory authorities indicating the desirability of certain procedures might well result in changed expectations. 
scoring of the lag time which certain categories of customer can expect. ${ }^{142}$ Such descriptions should be helpful in meeting the claim that a firm violated the antifraud rules by getting information to a particular customer more slowly than to other customers.

This procedure for disseminating investment advice does not, in our view, run afoul of the concerns manifested in Courtland, as long as its purpose is not to afford customers an opportunity to scalp. We recognize that a purpose test makes results in a specific case turn on subtle factual distinctions. For example, if the broker-dealer tells the customer only that a favorable research report will be issued, it is easy to conclude that he intends the customer to act on market information. A different presumption might attach where the customer receives the research report. At the time that a customer is given a favorable research report, the broker-dealer should be careful not to supply the kind of information which would lead the customer to buy with the expectation of selling out when the recommendation has produced a surge of demand from other customers. In other words, the brokerdealer should not give information with respect to the timing or method of any future dissemination of the report. However, making customers aware of the firm's general allocation policy should not normally be viewed as prohibited. Since the line between cases cannot be clearly drawn, the broker-dealer should be alert to repeated short-swing trading by customers who normally receive research recommendations early in the allocation process. Further, the broker-dealer should not trade discretionary accounts in a manner which permits an inference of scalping.

Our analysis suggests that in many situations an investment adviser or broker-dealer can limit purchase recommendations to a select group of customers. No case has yet suggested that a firm must communicate its purchase recommendations to every client who might be interested. Indeed, suitability concepts may make it inappropriate for a firm to recommend certain securities to certain types of customers. We conclude only that, when a firm recommends securities, it must not communicate them in a way which facilitates scalping or defeats legitimate customer expectations.

At the same time the SEC, in both administrative proceedings ${ }^{143}$

142 See O'Boyle, Broker-Dealer Conflict of Interest Problems, in 3D ANNJAL INSTrruTE, supra note 6, at 457, 486; Henderson, Conflicts of Interest for the Money Manager, in id. 293, 305 (comments of P. Loomis). SEC Investment Co. Act Release No. 7219 (June $9,1972)$ proposes disclosure guidelines for mutual fund prospectuses which would include a discussion of how the adviser allocates investment opportunities among clients. See also Herman \& Safanda, Allocating Investment Information, 29 FIN. ANax. J., Jan./Feb. 1973 , at 23.

143 Matter of Butcher \& Sherrerd, SEC Exchange Act Release No. 9402 (Nov. 24, 
and public statements ${ }^{144}$ has warned that a firm's obligations to its customers may be broader where it changes its view of a security which a customer has purchased or sold short on the firm's recommendation. The SEC has stated that:

a broker is obliged to communicate any material changes in his prior investment advice arising from subsequent research he may do to all customers whom he knows have purchased and may be holding shares on the basis of his earlier advice, at least under circumstances where to do so would not impose an unreasonable hardship on the broker. ${ }^{145}$

The SEC's statement does not impose a duty to follow up securities with respect to which a firm has made recommendations. ${ }^{140}$ A contrary result would, in effect, turn each brokerage account into a managed account. The SEC appears only to take the view that, if follow-up research produces a material adverse change in the firm's view of a security, that change in view should be communicated to the firm's customers.

The requirement that a firm notify its customers of material changes in its advice raises numerous practical questions. The SEC recognized the need for flexibility in solving these questions by conditioning the duty to notify on its not creating "an unreasonable hardship" on the broker. A threshold question in dealing with this requirement is determining when a material change in investment advice has occurred. In the Butcher $\&$ Sherrerd proceeding the firm, in effect, changed a buy recommendation to a sell recommendation. A duty to notify may, however, also be triggered where a buy recommendation is changed to a hold recommendation. Customers seeking to buy more of the stock through the firm in reliance on the previous advice should be informed of the change in view. In addition, in those cases where a

1971) ; Summary of Order for Public Proceedings, [1971-1972 Transfer Binder] CCH FED. SEC. L. REP. I 78,466 . This proceeding was settled. SEC Exchange Act Release No. 9894 (Dec. 11, 1972), [Current] CCH FED. SEC. L. REP. đT 79,135.

144 SEC, Statement on the Future Structure of the Securities Markets (Feb. 2, 1972), in 137 BNA SEC. REG. \& L. REP. pt. II, at 6.

$145 \mathrm{Id}$. This formulation retreats from an earlier, loosely constructed suggestion by the Chairman of the SEC that:

A broker making research conclusions on a company available to any customer will be called upon to make those conclusions known to all customers for whom he has purchased shares on the basis of earlier research on that company.

See Henderson, Conficts of Interest for the Money Manager, in 3D AnNoAr Instrrute, supra note 6 , at 309 n.25.

146 Several recent complaints appear to have charged, inter alia, that brokerage firms violated the antifraud provisions by continuing to recommend the purchase of certain stocks although the firms knew or should have known that the stocks were no longer good investments. E.g., Mascolo v. Merrill Lynch, Pierce, Fenner \& Smith, Inc., [Current] CCH FED. SEC. L. REP. II 93,645 (S.D.N.Y. Oct. 3, 1972); Odette v. Shearson, Hammill \& Co., 180 BNA SEC. REG. \& I. REP. A-17 (S.D.N.Y. filed Nov. 20, 1972). 
change to the hold category is understood to be a general sell signal, the obligations relating to sell recommendations also apply. It is not clear to what extent a true hold recommendation must be generally communicated because by its terms it does not call for customer action. A hold recommendation may simply indicate that a stock should be held for long-term growth rather than purchased for short-term gains, or that other available stocks offer more attractive investment opportunities. At the same time general circulation arguably is necessary where there has been a very recent active solicitation by the firm to buy the security or where customers otherwise reasonably believe that the firm continues actively to recommend the securities. ${ }^{147}$

Once a firm has changed its views on a particular stock, it must determine who its customers are and which of its customers to notify. Although it may be possible for a firm quickly to compile a list of all of its customers who are recorded as holding that stock, the list would probably include customers who did not purchase the stock in reliance on the firm's earlier advice and might not include some customers who did purchase it on reliance on the firm's earlier advice. For example, a new customer of the firm may have bought the stock before he became a customer. Many customers deal with a number of firms. Thus, some customers may have bought the stock from another broker, but in reliance on the firm's advice. Further, customers who bought the stock through the firm and took delivery of it may have sold the stock through a different firm. Since notification is not without cost and since identification of persons who relied on the firm's advice may involve considerable difficulty, firms should be given substantial leeway to develop a list of active customers who are readily identifiable from their records as present holders of the security. ${ }^{148} \mathrm{~A}$ good faith effort to avoid a pattern of discrimination in favor of selected groups of persons should be adequate.

In any event, when the firm makes a sell recommendation, it will have to notify all registered representatives that buy orders in the stock will be accepted only after the customer indicates that he under-

147 The SEC's articulation of the duty to notify seems to imply that it is only triggered by a material change in the firm's recommendation. In those cases where salesmen use firm recommendations only as broad guidelines for their own recommendations, they may be under a duty to communicate material changes in their individual views with respect to securities which their customers have bought and are holding.

148 The difficulty of identifying customers still holding a stock which is the subject of a sell recommendation has led one major brokerage firm to require, as a condition of receiving sell recommendations on a particular security, that the shares be left with the brokerage firm in "street name." The Bache Account Management Service transmits buy and sell recommendations on approximately 300 stocks to every customer on a computerized list who holds that particular stock and who has left it with Bache in street name. A letter is sent to each client on the list advising him of the recommendations and the reasons for the change and suggesting that he contact his registered representative. 
stands that the firm recommends that the stock be sold. This procedure will not necessarily alert the customer who learned of the firm's original buy recommendation, but who is now buying stock through another firm. However, it seems reasonable, under the circumstances, to limit the firm's responsibilities to customers who are actively purchasing the stock through it.

Once the appropriate list of customers is developed, the changed recommendation must be communicated. In contrast to purchase recommendations where we have suggested that a broker can notify his more important customers first, there are reasons for insisting that sell advice be communicated to all customers at the same time. Normally sell advice would have a more dramatic impact on market price than a purchase recommendation. First, purchases are normally sought to be made in a manner not to disrupt the market. On the other hand, sell advice may result in decisions to liquidate a position as promptly as practicable and reduce further anticipated losses. Second, purchase advice is often for longer-term investment. That is, the recommendation is usually not made for the quick term and may contemplate at least a modest holding period. Thus, timing of the purchase may not be crucial. On the other hand, sell advice is usually given with a view to prompt action. For these reasons, it may be argued that customers' expectations are for uniformity of treatment on the sell side. ${ }^{148}$

As suggested in our discussion of buy recommendations, it may be impossible to design a system which will provide the changed views to each customer at the same time. It should be sufficient that the firm adopt a procedure reasonably designed to prevent discrimination in favor of selected customers. That procedure probably requires some policing of registered representatives to see that they are rotating the order in which they notify their customers. ${ }^{150}$

IV. Disclosure in the Context of a Corporate Repurchase Plan

Another common situation involving self-generated, material, nonpublic market information is present when a corporation undertakes a program of repurchasing its own shares. ${ }^{151}$ Our discussion of this problem will center around XYZ Corporation's funding of a stock

149 BERNSTEIN, supra note 139, at 11, states that institutional customers are given sell recommendations, but not buy recommendations, simultaneously with discretionary accounts.

1502 Institutional Investor Study, supra note 49, at 348-49. See Henderson, Conficts of Interest for the Money Managers, in 3D AnNoar Instirute, supra note 6, at 293, 308-09 (remarks of Commissioner Loomis).

151 Corporate repurchase programs have grown relatively steadily since 1954. For a comprehensive discussion of these programs see C. EIIIS \& A. YoUNG, THe RapUrchase of Comaron STOCK (1971). For an indication of recent corporate interest in repurchasing stock, see Wall St. J., Mar. 7, 1973, at 21, cols. 3-4; id., Nov. 22, 1972, at 1, col. 6. 
option plan by purchasing its outstanding common stock, listed on the New York Stock Exchange, in market transactions. The plan to buy shares, rather than to issue new ones, is based on management's view that $\mathrm{XYZ}$ stock is presently undervalued. The number of shares to be repurchased will not be sufficient to cause a significant shrinkage in the capital base of the corporation. Thus, XYZ's earnings per share will not be affected materially; and XYZ's debt to equity ratio will not be materially changed. ${ }^{152} \mathrm{XYZ}$ has adequate cash reserves for the repurchase program. It is expected that XYZ's repurchase program will likely have a significant, albeit not precisely calculable, impact on the market price of XYZ common stock. There is no other material undisclosed information about XYZ.

It now appears settled that a corporation purchasing its own stock must disclose any material, non-public information it possesses about itself. ${ }^{153}$ For example, if XYZ discovers that land it owns contains valuable mineral deposits which can be commercially exploited, it may not purchase its stock until disclosure with respect to that discovery has been made. Failure to disclose would result in XXZ's purchases allocating a portion of the increased value attributable to the newly discovered mineral deposits from the shareholders who sell their stock to those who do not. Although it is true that prior to public disclosure those who sell out may lose this increment in value to strangers to the corporation or other shareholders who are equally ignorant of the discovery, it seems particularly unfair to permit the shift in value to occur within the corporation. The holders of a class of securities assume that they will be exposed to identical risks of loss and opportunities for gain and that management will not act in a way which treats any particular group within the class preferentially. Those expectations should not be defeated by market activities of the corporation.

In addition, management's judgment on the appropriate timing of the disclosure of corporate events should not be subjected to pressure to buy stock for the corporation at as cheap a price as possible. This pressure would be felt most severely in those cases where management itself owns a substantial amount of the corporation's stock and would thus benefit from purchases made in the absence of disclosure. The first decision under rule $10 \mathrm{~b}-5$ involved just such a case. ${ }^{154}$

162 If XXZ's earnings per share were significantly affected or its debt to equity structure significantly changed, the repurchase program might be viewed as material corporate information. Such information would probably have to be disclosed. See text accompanying notes 153-54 infra.

183 See 3 L. Loss, supra note 23, at 1453-54; 6 id. at 3571-72.

154 Ward La France Truck Corp., 13 S.E.C. 373 (1943). The corporate purchases in all the early $10 \mathrm{~b}-5$ cases appear to have been motivated by insiders with large individual holdings. 3 L. Loss, supra note 23, at 1453. 
Management's inability to trade directly on inside information makes it inappropriate to allow management to do so indirectly.

Since XYZ is obligated to disclose all material, non-public corporate information it possesses prior to funding its stock option plan with market purchases, it becomes important to inquire whether management's judgment that XYZ stock is undervalued must be disclosed. No case has so held. ${ }^{155}$ Disclosure of management's judgments about the company's prospects appears to be required only when they crystallize into earnings per share estimates which deviate substantially from the range of estimates circulating in the market. ${ }^{156}$ Typically management's estimate of per share earnings deviates substantially from the estimates in the market only where management has become aware of some material facts, such as the loss of important customer orders, which have not yet become generally available. However, there does not seem to be evidence showing that management normally has superior ability to judge the validity of the capitalization ratio which the market places on earnings. ${ }^{157}$ Thus, apart from knowledge of unexpected earnings performance, management's judgment about the validity of current market value probably would not be considered material. ${ }^{158}$

Even if XYZ possesses no material, non-public corporate information, the literature suggests, ${ }^{159}$ and the practice appears to $\mathrm{be},{ }^{160}$

1556 L. Loss, supra note 23 , at 3584.

156 See Dayan, Correcting Errors In the Press, 5 Rev. of Sec. Reg. 941 (1972). See also American Stock Exchange Company Gume \& 403(3) (May 20, 1970):

In the case of a rumor or report predicting future sales, earnings or other data, no response from the company is ordinarily required. However, if such a report is manifestly based on erroneous information, or is wrongly attributed to a company source, the company should respond promptly to the supposedly factual elements of the rumor or report in the same manner as to other false rumors and reports of a supposedly factual nature. Moreover, if a rumor or report contains a prediction that is clearly erroneous, the company should issue an announcement to the effect that the company itself has made no such prediction and currently knows of no facts that would justify making such prediction.

In its recent release announcing its intention to issue rules on projections, the SEC suggested that the furnishing of forecasts to any outsider would be treated as "a material event that requires the same full and immediate disclosure as other material events ...." SEC Securities Act Release No. 5362 (Feb. 2, 1973). Public disclosure would seem to be required whether or not the projection deviated in any way from market expectations.

157 There is evidence that corporate insiders fare better in their trading than the market as a whole. However, this advantage has been explained as reflecting their better ability to judge internal corporate events rather than any greater acumen in judging the market. See Friend, The SEC and the Economic Performance of Securities Markets, in Economitc Policy and the Regulation of Corporate Securities 185, 204 (H. Manne cd. 1969). See also C. Ellis \& A. Young, supra note 151, at 149-50.

158 If management's judgment of the validity of current market value were material, management's own purchases and sales of company stock in effect would have to be limited to programs outside management's control.

158 E.g., Harrison, Corporate Stock Repurchase Programs: SEC and Other Problems, in 2D ANNUAL INSTTIUTE, supra note 43, at 211, 213-15 (1971).

160 See, e.g., N.Y. Times, Dec. 16, 1972, at 49, cols. 7-8: 
that advance disclosure of the proposed repurchase program should be made. ${ }^{101}$ In part these suggestions are premised on the view that the program itself will have an impact on the market price of the stock and that shareholders should be informed of it. ${ }^{162}$ Shareholders would then have an equal opportunity to share in the premium the corporation is prepared to pay to accomplish its repurchase program. Moreover, third persons encouraged to buy by the impact of the program will be warned that the price action may be due to a temporary phenomenon. ${ }^{163}$ Further, management's decision to repurchase stock has been characterized as a quiet way of paying (or increasing) a dividend at a time when management is not certain that future operations will warrant the continuance of such dividend. It also indicates that management has no better alternative use for the cash used to buy the stock. It has been argued that, by analogy to the requirement for disclosing dividend action, management should be required to disclose this quasi-dividend action. ${ }^{164}$

These arguments for advance disclosure would be fully persuasive if advance disclosure did not increase the cost of accomplishing the program. As long as there is no undisclosed corporate information which would affect the market's assessment of XYZ stock, the price

The Buffalo Forge Company said it may purchase up to 50,000 shares of its own common either on the open market or through private transactions. The shares purchased will be used for employe [sic] stock options and future acquisitions. The company's stock closed at $27-7 / 8$, up $1 / 4$ on the Big Board.

Directors of Granite Management Services, Inc., have authorized the purchase of up to 100,000 common shares of the company on the open market. The company's stock was up $1 / 4$ at $5-5 / 8$ on the American Stock Exchange.

161 AMrertcan Stock Exchange CoMrant GuIDe \& 403(1) (May 20, 1970) also recommends disclosure of corporate repurchase programs. Further, $\S 23(c)(1)$ of the Investment Company Act of 1940, 15 U.S.C. $\$ 80 a-23$ (c) (1) (1970) conditions stock repurchases by closed-end investment companies on notice of an intent to repurchase having been given to shareholders within the six months preceding the purchases. See id. Rule 23c-1, 17 C.F.R. \$ $270.23 c-1$ (1972). On the other hand, in the case of non-closedend investment companies, the SEC has only required advance disclosure of a repurchase program in the case of a company whose securities are the subject of a tender offer. See 1934 Act Rule 13e-1, 17 C.F.R. \& 240.13e-1 (1972). Disclosure of a repurchase program is not required by proposed rule 13e-2, 35 Fed. Reg. 11,410 (1970), which deals with repurchase programs generally.

162 C. ErIIs \& A. Younc, supra note 151, at 148-52, present reasons which, in their judgment, seem to have convinced the academic and financial communities that a corporate reacquisition program will have a favorable price impact on the security. They conclude, however, that empirical evidence shows that stock repurchase programs harbinger a drop in the stock price, both absolutely and relative to the market averages. They caution that their results do not necessarily disprove the claim that the repurchase program itself has a bolstering effect on a company suffering a general price decline. Id. 165-66.

103 If warning third persons imposes increased costs on the corporation, it is doubtful that the corporation would have an independent obligation to inform persons with whom it has no dealings. The case seems analogous to the situation where, in the absence of trading, a corporation has a good business reason for not disclosing material corporate information.

164 See V. Brudney \& M. Cemrelstein, Cases and Materiats on Corporate Finance 464 (1972). 
of $\mathrm{XYZ}$ prior to the repurchase program represents the market's best estimate of the value of $\mathrm{XYZ}$ stock in comparison with alternative investments (XYZ's equilibrium price). Any XYZ purchases at that price treat holders and sellers of XYZ stock equally. Unlike the change in equilibrium price caused by disclosure of corporate information, any price rise or retarding of a price decline attributable to $X Y Z$ 's purchase program and its advance disclosure probably will be temporary. Absent disclosure of other material information, XYZ stock should fall to its former equilibrium price upon completion of the purchase program.

Nondisclosure of XYZ's purchase program may arguably result in the fairest treatment of all the stockholders. The premium over equilibrium price resulting from XYZ's market purchases will be distributed at random, among selling shareholders. Since the purchases are made in the market, all shareholders have an equal opportunity to sell their shares. Any increased cost of the repurchase program attributable to its advance disclosure would benefit the selling shareholders and must be borne by the non-selling shareholders.

The argument against advance disclosure rests on the assumption that this disclosure would increase the cost of the repurchase program. Wall Street wisdom assumes that in many cases announcing the program will have an immediate and continuing impact in raising the price or retarding a decline, presumably because the market is made aware of the presence of additional demand for the stock. ${ }^{165}$ We have found no persuasive, empirical evidence exploring the validity of that assumption.

If advance disclosure increases the cost of the repurchase program, the extra cost might nevertheless be justified if the premium attributable to advance disclosure were shared among a greater number of shareholders. However, disclosure alone probably would not assure such a result. Maximization of the number of shareholders participating in the premium would be achieved if corporate repurchases were required to be made through a tender offer in which shares are accepted on a pro rata basis. ${ }^{160}$

165 Compare Fleck, Corporate Share Repurchasing: An Informal Discussion, 41 HARv. BUS. ScH. BULI., Jan.-Feb., 1965, at 10, 12 (statement of Robert Vandell) and Wall St. J., Mar. 7, 1973, at 27, col. 6 (west coast ed.) (Analysts say "company's announced plan to repurchase its own shares tends to buoy the market price of those shares,") with 43 HARv. BUS. REV., May-June, 1965, at 36 (letter to the editor from Edward G. Shufro, Partner, Shufro, Rose \& Meyer):

(1) Surprising as it may seem, in practice as opposed to theory, the announcement of a repurchase program of even significant dimensions has very little or no discernible effect on market price, as a rule, except for tenders well Id. 38 . above market.

${ }^{166} \mathrm{~A}$ suggestion along these lines has been made by Professor William L. Cary. See Cary, Corporate Repurchases of Stock: State Law and Policy, in 2D ANNUAL INSTITUTE, supra note 43 , at 225, 235. 
Failure to disclose corporate repurchase programs could also be justified on the ground that the program will not have a substantial impact on market price and, therefore, is not material. Ordinarily, purchases are effected under guidelines proposed by the SEC to minimize price impacts. ${ }^{107}$ Although these guidelines do not foreclose a cumulative impact on market price, ${ }^{168}$ courts might be reluctant to label as material a repurchase program conducted under the SEC's proposed guidelines because market price is subject to many factors and it is difficult to predict with any certainty the impact of carefully placed purchases. ${ }^{\mathbf{1 6 9}}$

Management might determine that its stock can most efficiently be acquired by a tender offer at a premium above market price. Even if management decides to make a tender offer, it might seek to minimize total acquisition costs by purchasing stock in the market prior to the announcement of the offer. ${ }^{170}$ However, this practice may be subject to question. Unlike the market purchases previously considered, management has made a very specific judgment about the price it is willing to pay for a substantial amount of securities. In this respect the situation is similar to the crystallization of judgment involved in estimating earnings per share. Consequently, it may be urged that this specific, management developed information about the corporation should be used to benefit all shareholders equally. That argument finds support in Steven v. Hale-Haas Corp., ${ }^{171}$ in which the court indicated that a corporation cannot discriminate among members of a class of security holders by purchasing their securities in the market shortly before redemption at a higher price. ${ }^{172}$

\section{Disclosure by Professionals with Access to MaRKET INFORMATION}

This final section of the article will examine certain of the restrictions on the activities of professionals that are assigned or take

107 Proposed rule 13e-2, 35 Fed. Reg. 11,410 (1970).

108 In any event the corporation's purchases might act as a stabilizing influence or eliminate the depressing influence of a block of stock overhanging the market.

109 For a discussion of materiality in the context of market information, see notes 20-22 supra \& accompanying text.

170 See A. Brommerg, supra note 5, § 7.3(3), at 161; Note, Corporate Stock Repurchases Under the Federal Securities Law, 66 CoLUMr. L. Rev. 1292, 1295 (1966).

171249 Wisc. 205, 231-32, 23 N.W.2d 620, 632-33 (1946) (dictum).

172 See Note, 59 Harv. L. Rev. 769, 777 (1946); Cf. Latty, Fairness-The Focal Point in Preferred Stock Arrearage Elimination, 29 VA. L. Rev. 1, 16-17, 47 (1942).

A recent request for an exemption under rule 10b-13 suggests the depth of a company's conviction that market purchases of its securities could only be made after prior disclosure of a contemplated tender offer for them. See United Brands, avail. Jan. 19, 1973. The company's disclosure of the impending offer for its convertible debentures triggered the rule's prohibition against market purchases and thus made the request for an exemption necessary. The staff refused to grant the exemption. 
specific roles in the trading market and as a consequence receive special access to market information. In its recent release accompanying rule $19 \mathrm{~b}-2$, the SEC stated that its concern

for the fair and equal treatment of all investors has also lead [sic] to a continuing analysis of exchange rules regulating specialist trading, block positioning, floor trading and offfloor trading, since it is the center of the exchange marketplace where the potential use and misuse of market information resulting from trading activity in a particular security is most susceptible to exploitation. ${ }^{173}$

Restrictions on specialists and floor traders have been worked out in detailed rules of the SEC and the self-regulatory organizations. These restrictions, however, have not historically been grounded in the antifraud provisions of the securities laws, but appear to have been developed primarily under the SEC's broad powers under section 11 of the Exchange Act-measured by considerations of the "public interest" and the "protection of investors"174_or by the exchanges under the broad authority to regulate the conduct of their members, including the power to establish "just and equitable principles of trade."175 These rules represent, in the broadest sense, an effort to delineate the proper structural characteristics of a marketplace and the role of its participants. Misuse of market information has been just one consideration in their formulation.

A major set of unresolved questions in this field relates to the extent to which restrictions similar to those governing the trading activities of specialists and floor traders should be applied to other market participants, such as over-the-counter market makers and block positioners. As the movement toward a central marketplace accelerates, a reexamination of the need for comparable regulation will also accelerate. Because market traders and block positioners are engaged in continuous activity requiring rapid decisionmalsing and a breach of standards can result in serious sanctions, any rules developed should be as specific as possible. In addition, these rules will

173 SEC Exchange Act Release No. 9950, at 115-16 (Jan. 16, 1973).

174 The SEC has specific power under $\S 11(\mathrm{~b})$ of the Securities Exchange Act, 15 U.S.C. $\$ 78 \mathrm{k}(\mathrm{b})(1970)$, to adopt rules regulating specialists' activities, and under $\$ 11$ (a), $i d$. $\$ 78 \mathrm{k}(\mathrm{a})$, to regulate floor trading by members of securities exchanges for their own or discretionary accounts.

175 Section $6(\mathrm{~b})$ of the Securities Exchange Act, id. \& 78f(b), requires that the rules of a registered exchange provide for the disciplining of a member for conduct inconsistent with just and equitable principles of trade. See also $\$ 11(\mathrm{~b})$, id. \& 78k(b) (rules governing specialists and odd-lot dealers), and $\S 19(\mathrm{~b})$, id. $\$ 78 \mathrm{~s}(\mathrm{~b})$ (various subjects as to which it is contemplated that an exchange will exercise authority). See Staff of the Subcomar. on Securities, Senate Comar. on Banktng, Housing and Urban AffaIrs, 93D Cong., Ist Sess., Securities INDUSTRX StUdy 157-58 (1973). 
seek to achieve policy goals broader than simply barring the improper exploitation of market information. For these reasons, we would expect that regulation will develop primarily through rulemaking, rather than through efforts to apply rule $10 \mathrm{~b}-5$ to particular transactions.

This is not to say that rule $10 \mathrm{~b}-5$ would be inapplicable to a market professional who utilizes information given to him for a particular purpose to disadvantage his customers. ${ }^{178}$ Thus, a block trader given a sell order to execute by a customer undoubtedly could not sell ahead of his customer. ${ }^{177}$ The preferred access to information granted certain professionals could be a foundation for inferring certain expectations, at least on the part of investors dealing with those professionals.

\section{A. Specialist Regulation}

New York and American Stock Exchange specialists have what is in effect an exclusive franchise to make the market on the exchange in an assigned stock. ${ }^{178}$ As a consequence of his position, the specialist sees the flow of orders in his stock ${ }^{179}$ and often knows or can

176 A Note appropriately entitled The Downstairs Insider: The Specialist and Rule $10 b-5,42$ N.Y.U.L. REv. 695 (1967) takes the position that the specialist is subject to rule $10 \mathrm{~b}-5$ restrictions because of his special relationship to the corporation in whose stock he specializes. However, the discussion in the Note centers primarily on material, nonpublic information about the corporation rather than information about the market in its stock. It discloses no instance in which action under rule $10 \mathrm{~b}-5$ has been taken against a specialist who abused his privileged access to market information.

177 See Opper v. Hancock Sec. Corp., 250 F. Supp. 668 (S.D.N.Y. 1966) ; NYSE Rule 92, 2 CCH N.Y. STock ExcH. GUIDE 72092 (1972) [hereinafter cited as NYSE GUIDE] (a firm cannot execute an order for itself while it holds an unexecuted customer order). Cf. Silverman v. Bear, Stearns \& Co., 331 F. Supp. 1334 (E.D. Pa. 1971) (a firm is under no duty to tell a customer that it is buying a security it also bought for the customer).

178 For general descriptions of specialist activities, see G. LEFFLER, THE STOCK MARKET 203-18 (3d ed. 1963); 2 L. Loss, supra note 23, at 1201-08; 5 id. at 3206-25; New York Stock Exciange, Now About the Specialist (1969); S. RobeIns, ThE Securities Markets-Operations and IssUes 191-201 (1966); B. SchUltz, The SecurIties Market-ANd How It Works 124-52 (Rev. ed. A. Squier 1963); Speciar Study, sulpra note 26, pt. 2, at 57-171; Hearings on Self-Regulation in the Securities Industry Before the Subcomm. on Securities of the Senate Comm. on Banking, Housing and Urban Affairs, 92d Cong., 2d Sess., pt. 4, at 1-216 (1972) (Case Study on Regulation of Specialists on the New York and American Stock Exchanges) [hereinafter cited is Senate Case Study]; Fiske, Can the Specialist System Cope With the Age of Block Trading?, 3 Tage INSTITUTIONAI INvestoR, Aug., 1969, at 29, reprinted in 2 SEC. L. Rev. 559 (1970) [hereinafter cited as Fiske]; Robertson, The Unreconstructed Specialists, 84 FORTUNE, Aug., 1971, at 183; Wolfson \& Russo, The Stock Exchange Specialist, 4 Rev. SEc. REg. 897 (1971); Wolfson \& Russo, The Stock Exchange Specialist: An Economic and Legal Analysis, 1970 DUKE L.J. 707 [hereinafter cited as Wolfson \& Russo]; Note, The Downstairs Insider: The Specialist and Rule 10b-5, 42 N.Y.U.L. Rev. 695 (1967).

179 The growth of institutional trading and the emergence of competing markets have resulted in the specialist in some stocks not seeing a significant portion of the flow of orders for that stock. For example, an active third market dealer claims that in some NYSE stocks it accounts for more than $100 \%$ of the NYSE volume. Advertisement by Weeden \& Co., Inc., 7 The Insturutional Investor, Jan., 1973, at 43. Similarly, specialisis may not be aware of block trades until the brokerage house handling the trade brings it to the exchange floor for execution. Cf. 4 Instirutionax INvESTOR Study, sapra note 49, at 1599. The Study found that specialists' participation rate in block trades was greatest 
guess the identity of those presently interested in purchasing or selling stock. He also has exclusive access to the "book" of all orders away from the current market price which other exchange members have left with him for execution. ${ }^{180}$ In addition to handling these orders as a broker, the specialist acts as a dealer for his own account in performing the statutorily dictated function of maintaining a fair and orderly market. ${ }^{181}$ The Special Study concluded that access to the book gave the specialist "a definite trading advantage over other market participants,"182 because the book reflected public interest in the security and in certain instances was an important indicator of short-term price movements. ${ }^{183}$

The specialist is given these informational advantages so that he may "assist in the maintenance, so far as practicable, of a fair and orderly market."184 Indeed, the specialist is broadly prohibited by the Exchange Act from effecting transactions for his own account for any other purpose. ${ }^{185}$ Specific rules have been written to limit the use the specialist may make of the superior information with which he is supplied and to regulate his trading activities. For example, a specialist normally must avoid participating as a dealer in opening or reopening a stock in such a manner as to upset the public balance of supply and demand. ${ }^{186}$ One of the block positioning rules recently adopted by the New York Stock Exchange states that, after a specialist has learned of a block transaction, he "should maintain the same depth and normal variations between sales as he would had he

in block trades of less than $\$ 1$ million, where assembly of participants is more directly related to the floor. Id. at 1598 .

180 For an example of a page from a specialist's book, see SpEcIad Study, supra note 26 , pt. 2 , at 491 .

1811934 Act \& 11(b), 15 U.S.C. \& $78 \mathrm{k}(\mathrm{b})$ (1970).

182 SPECIAT STUDY, supra note 26 , pt. 2 , at 166.

183 Id. at 166; Wolfson \& Russo, supra note 178, at 710 .

1841934 Act Rule 11b-1(a)(2)(ii), 17 C.F.R. \& 240.11b-1(a)(2) (ii) (1972); accord, NYSE Rule 104.10, 2 NYSE GUIDE \2104.10 (1967); ASE Rule 170(b), 3 ASE GUDE II 9310 (1971).

1851934 Act $\S 11$ (b) provides:

If under the rules and regulations of the Commission a specialist is permitted to act as a dealer, or is limited to acting as a dealer, such rules and regulations shall restrict his dealings so far as practicable to those reasonably necessary to permit him to maintain a fair and orderly market....

15 U.S.C. $\& 78 \mathrm{k}(\mathrm{b})(1970)$.

186 NYSE Rules 104.10(5), 104.10(6), 104.11, 2 NYSE Gume If 2104.10, 2104.11 (1967); ASE Rules 170.01, 170.02, 170.04 (commentary), 2 ASE GumE II 9310 (1969). Those rules permit specialist participation if the condition of the general market or the specialist's position in light of the reasonably anticipated needs of the market make his participation advisable. See 2 NYSE GUIDE II 2115A.20 (1965). The Special Study found that specialists' control over the price of stock at openings is particularly significant. Speciax Study, supra note 26, pt. 2, at 137-42, 165, 168. Thus, it is important to prevent their judgment in opening a stock from being skewed by opportunities for personal profit. 
not learned of the block."187 The specialist is limited in the manner in which he can deal with the book: he is prohibited from "cleaning up the book"188 and in successive transactions with the book he must give all orders the best price which any of them receive. ${ }^{189}$ Other rules limit the specialist in using his superior knowledge to compete with public customers. Thus, if a specialist participates in a block of stock at the "clean up" price, all executable public orders must also receive the benefit of that price. ${ }^{190}$ Still other restrictions prevent the

187 NYSE Rule 127(a), 2 NYSE GuIDE II 2127 (1972). The American Stock Exchange has not adopted special rules governing the conduct of block positioners.

In a magazine article published prior to the adoption of NYSE Rule 127, two traders for a large mutual fund complex indicated how it would be possible for a specialist to profit by moving the price of a security upon learning of a pending block trade. The traders entered a small order for 700 shares of a very expensive stock when the market price was $\$ 254$ per share. After telephoning the order to a broker, one of the traders saw some shares of the stock at $\$ 252$, down $\$ 2$. A few minutes later he saw his own order cross the tape at $\$ 254$, and shortly thereafter the stock was down to $\$ 252$ again. After checking with their broker, the traders confirmed that the specialist had sold short to fill their order at $\$ 254$ and then immediately covered his short sale at $\$ 252$, thereby earning a profit of $\$ 1400$. Horror Stories, 108 ForBes, Sept. 15, 1971, at 43,44 .

188 NYSE Rule 104.10(5)(B), 2 NYSE GUIDE ( 2104.10 (1967); ASE Rule 170.01(b) (commentary), 2 ASE GUIDE If 9310 (1971). The NYSE rule provides in pertinent part:

(5) ... The following types of transactions to establish or increase a position are not to be effected except when they are reasonably necessary to render the specialist's position adequate to [the needs of the market]:

$\cdots$

(B) the purchase of all or substantially all the stock offered on the book at a price equal to the last sale, when the stock so offered represents all or substantially all the stock offered in the market; and when a substantial amount of a stock is offered at a price equal to the last sale price the purchase of more than $50 \%$ of all the stock offered;

-.

Transactions of these types may, nevertheless, be effected with the approval of a Floor Official or in less active markets where they are an essential part of a proper course of dealings and where the amount of stock involved and the price change, if any, are normal in relation to the market.

If the specialist were permitted to clean up the book, he would have greater control over the market price of the security. For example, a specialist who was aware that a block trade would shortly occur at a premium over the market price could purchase all the stock offered on the book for his own account at the market price and resell that stock at the premium in connection with the block trade. The specialist's participation in block transactions is presently limited to his reasonable needs in light of his obligation to maintain a fair and orderly market following the block transaction. See note 190 infra.

180 NYSE Rule 104.10(8), 2 NYSE Gume đI 2104.10 (1967); ASE Rule 155.02 (commentary), 2 ASE GUDE If 9295 (1969). NYSE Rule 104.10(8) provides:

If a specialist has limit sell orders on his book at two or more different prices, he should not, as a dealer, purchase all of the stock from the book at the lowest limit price and then immediately purchase stock from the book at a higher limit price. He should in such a situation withdraw the offer and cross the entire amount of stock he is purchasing as a dealer at one price. The same principle applies in the event the specialist sells stock to limit orders on the book at two or more different prices.

NYSE Rule 91, 2 NYSE GumE I 2091 (1972), and ASE Rule 152, 2 ASE GumE If 9292 (1971), generally regulate members' principal transactions with their customers. 190 NYSE Rules 104.10(7), 127, 2 NYSE Gume If 2104.10 (1967), 2127 (1972); ASE Rule 155.01 (commentary), 2 ASE GoIDE \ 9295 (1969). NYSE Rule 104.10(7) and ASE Rule 155, known as the "gapping rules," were adopted as the result of a finding by the Special Study that possible fiduciary problems were involved when the specialist 
specialist from letting other persons take advantage of his market information. The effect of Section 11(b) of the Exchange Act is to make it unlawful for a specialist to disclose the content of his book unless he makes it available to all members of the exchange. That section also permits a specialist, acting as a broker, to execute only market or limited price orders. ${ }^{191}$ The premise is that a specialist should not be able to use the special market information he receives to exercise discretion with respect to the timing or price of an execution.

The superior information to which the specialist is given access is susceptible to abuse in favor of his own customers. Indeed, the Special Study identified a number of instances in which specialists had succumbed to the temptation to give preferential treatment to their private customers. ${ }^{192}$ As a consequence, the Study recommended that specialists and their firms should not be permitted to have their own retail customers. ${ }^{193}$ However, the rule ultimately adopted only

participated in a block trade at a better price than he obtained for his customers on the book. Speciar STUDy, supra note 26, pt. 2, at 137. At the time of the Institutional Investor Study, the NYSE gapping rule did not give the benefit of the clean-up price to any book order at the current bid or offer, to stop orders, or if the specialist did not discuss the block with the brokerage firm handling the trade prior to execution or did not participate for his own account at the clean-up price. For a discussion of the problems raised by the operation of the gapping rule in this manner, see 4 INSTTrUTIONAI INVESTOR STUDY, supra note 49 , at 1604.05 , and sources cited therein.

NYSE Rule 127, dealing with block positioning, has superseded the gapping rule. Rule 127(b) provides that, prior to the execution of a block trade, the broker handling the block trade shall ask the specialist to substitute his own quotation as a dealer for one unit of trading at the current bid or offer in the stock, unless such current bid or offer is on behalf of a Registered Trader, odd-lot dealer, or a member or member organization known by the broker handling the order to be acting for his or its own account. If this procedure is followed, book orders at the current bid or offer receive the benefit of the discount or premium associated with the block trade. Rule 127(b) also describes in detail procedures which the broker handling the trade may follow to reduce the number of shares allocated to public orders.

ASE Rule 155.01 similarly provides that, if a block of stock is sold at the clean-up price and the specialist purchases part of the block for his own account, he must execute all executable buy orders on the book at the same price, except for the amount of the block which can be executed at the current bid. Unlike the NYSE rule, however, ASE rule 155.01 provides that a block may be sold at different price limits on the book. In that case the specialist should to the extent practicable buy round lots for his own account at each price limit below the current bid and should divide his purchases into round lots of approximately equal size among the price limits below the current bid at which he participates.

191 See NYSE Rules 123.20 (Supplementary Material), 123.44 (Supplementary Material), 2 NYSE GUDE If 2123A.20, 2123A.44 (1972); ASE Rule 154, 2 ASE GUIDE II 9294 (1969). The specialist also handles stop-loss orders which are a combination of limited price and market orders. See 5 L. Loss, supra note 23, at 3207-08. A not held order is an order in which the broker uses his discretion in the timing and price of execution. See id. NYSE Rule 123.44 and ASE Rule 154.03 ban the specialist from accepting such orders. It has been stated that "[t]he danger in these orders is that the great discretion given to specialists would permit them to manipulate prices." Wolfson \& Russo, supra note 178 , at 734 n.114.

192 SPECIAL STUdy, sutpra note 26, pt. 2, at 159.

193 Id. 166. 
precludes the specialist from accepting orders in his specialty stocks from certain corporate insiders and institutions. ${ }^{194}$

\section{B. Floor Traders}

Exchange members who are able to execute transactions for their own account on the floor of the exchange (floor traders) constitute another group which is given a privileged position over other users of the marketplace. Floor traders do not have to bear the normal exchange commission charge (even the costs of floor brokerage are eliminated) and they have an opportunity to observe and act instantaneously on floor developments. ${ }^{195}$ The Special Study observed that "[o]nly some strong demonstrable, countervailing public benefit can justify the special advantages enjoyed by the floor trader."186 Since the Special Study was not able to identify any particular market benefits from floor trading activities as they then existed, it recommended the gradual abolition of floor trading. It also offered an alternative under which an exchange plan might be developed to make floor trading an auxiliary to the specialist's market making function. In its 1964 proposal to restrict floor trading, the SEC characterized as

194 NYSE Rule 113, 2 NYSE GoIDE $\int 2113$ (1972). NYSE Rule 113(a) and ASE Rule 190(b), 2 ASE Gume II 9330 (1971), prohibit the specialist from accepting an order for the purchase or sale of any stock in which he is registered as a specialist directly (1) from the company issuing such stock; (2) from any officer, director or $10 \%$ stockholder of that company; (3) from any pension or profit-sharing fund; (4) from any institution, such as a bank, trust company, insurance company, or investment company. The Commentary to ASE Rule 190 also prohibits a specialist from engaging in any solicitation for the purpose of encouraging or discouraging the purchase or sale of specialty issues.

Two other sections of NYSE Rule 113 also deal with the Special Study's concern that the specialist might give preference to his public customers. Rule 113(b) provides that, with limited exceptions, an order given to a specialist for the purchase or sale of a security in which he is registered as a specialist shall not indicate the account for which the order is entered. Rule 113(c) and ASE Rules 190(c), (e) require the specialist to report to the exchange such information as the exchange may require with respect to transactions in stocks in which the specialist is registered for any account which is carried by the specialist's member organization, is serviced by the specialist or his member organization or is introduced by him or his member organization to another member organization on a disclosed basis.

195 The SEC has stated:

Commission studies make it clear that floor trading possesses special characteristics which result from floor traders' presence on the floor. From this strategic position, trading activity may be observed minutes before it appears on the tape, and bids or offers may be made or withdrawn in a matter of seconds. In addition, presence on the floor carries with it the benefit of what has been termed the "feel of the market" $\rightarrow$ a heightened sense of market tenor and trend. This is attributable, among other things, to the exchange of observations among fioor members, and familiarity with the trading techniques of specialists or floor brokers, with a resulting ability to foresee short-term market movements by informed observation of the activities of other persons on the floor.

This position has important consequences. Being first on the scene as a market movement commences, the floor trader can buy stock quicker and at a lower price, or sell it quicker and at a higher price. This, of course, is done at the expense of some members of the public.

106 SPECIAL STUDY, supra note 26, pt. 2, at 240. 
fraudulent the use by floor traders of the market information to which they had special access:

For example, a floor trader, familiar with the fact that certain commission brokers handle a large number of orders and do not execute them all at once, can anticipate from their appearance in the market that further substantial buying is forthcoming; and, it is extremely doubtful whether trading on this information, which is unavailable to the investing public, is consistent with 'fair dealing' or with the antifraud provisions of Rule 10b-5 under the Exchange Act. ${ }^{197}$

The New York and American Stock Exchanges ultimately embraced the alternative and each filed a plan which sought to regulate floor trader activity to prohibit destabilizing transactions and to make such trading contribute to the orderliness of the market. ${ }^{198}$ Neither the Special Study nor the SEC sought to impose special controls on floor trading in dually listed stocks on regional stock exchanges. Access to the regional stock exchange floor did not appear to provide special informational advantages. ${ }^{199}$ However, the advent of the central market system has caused the SEC to reconsider its conclusions about the advisability of permitting unrestricted floor trading on regional stock exchanges. ${ }^{200}$

\section{Other Exchange Members}

Exchange members, other than registered floor traders and specialists, may also enjoy trading advantages not normally available to the public. The Chairman of the SEC recently described those advantages in the following way:

The trading advantages which accrue to an exchange member are considerable. He may trade for his own accounts at the intra-member rate or without the payment of any commission charge, enabling him to take advantage of minor short swing price fluctuations by in and out trading. . . .

107 SEC Exchange Act Release No. 7290 (Apr. 9, 1964), in [1961-1964 Transfer Binder] CCH FED. SEC. L. REP. If 76,989, at 81,642-43.

198 The exchange programs established capital requirements for floor traders, NYSE Rule 111(b) (1), 2 NYSE GUDE $\Uparrow 2111$ (1969); ASE Rule 110(c), 2 ASE GumE $\pi$.9260 (1969); segregated the functions of floor broker and floor trader during the same trading session, NYSE Rule 112(b), 2 NYSE GuDE \ 2112 (1972); ASE Rule 111(c), 2 ASE GuIDE If 9261 (1969); required the floor trader to yield to orders from off the floor, NYSE Rule 112(c), 2 NYSE GUDE III 2112, 2112.24 (Supplementary Material) (1972); ASE Rule 111(d), 2 ASE GODE If 9261 (1969); prohibited congregation and domination in a particular stock, NYSE Rule 110, 2 NYSE GuIDE IT 2110, 2110.10 (Supplementary Material) (1969); ASE Rule 111(a), 2 ASE GUDD I 9261 (1969); and required 75\% of the floor trader's transactions to be stabilizing, NYSE Rule 112(d), 2 NYSE GUDE II 2112 (1972); ASE Rule 111(e), 2 ASE GUDE II 9261 (1969).

199 SPECTAL Study, supra note 26 , pt. 2, at 242.

200 SEC Exchange Act Release No. 9950, at 128-29 n.393 (Jan. 16, 1973). 
Moreover, a member receives a constant input of trading information from the floor and from other members. He has an intimate feel of trading conditions-for example, the size and nature of volume-in the market as a whole and in particular securities. This knowledge, combined with an understanding of the ways in which market professionals such as specialists and block positioners acquire and work off large positions, enables the member to maximize profit on his trading decisions.

Perhaps even more importantly, the member can make and implement trading decisions much more quickly than members of the investing public because of his proximity to information sources and, if present on the floor, his access to the specialist's post. ${ }^{201}$

The direction of regulatory philosophy appears to be that exchange members should not be allowed to benefit from the advantages conferred by their special status unless permitting them to do so, on balance, strengthens the securities markets. ${ }^{202}$ This philosophy is illustrated by exchange rules concerning member trading in connection with the execution of block orders.

A block trade involves an order which is too large to be absorbed in the ordinary course of the auction market. ${ }^{203}$ Its execution price is, therefore, typically negotiated between the parties and often involves a more than one percent discount from or premium over the current market price. ${ }^{204}$ In the case of block trades initiated by sellers, which

201 Address by SEC Chairman Casey, The Economic Club of New York, Mar. 8, 1972, in 143 BNA SEC. REG. \& L. REP. G-1, G-3 (Mar. 15, 1972). There is disagreement whether exchange members not present on the floor of an exchange enjoy informational advantages over large institutional traders. For a position to the contrary, see Statement of Donald M. Feuerstein, General Partner and Counsel, Salomon Brothers, at Hearings on S. 470 and S. 488 Before the Subcomm. on Securities of the Senate Comm. on Banking, Housing and Urban Affairs, 93d Cong., 1st Sess., at 7-9 (Feb. 21, 1973).

202 See text accompanying note 222 infra.

2034 InstITUTIONAL INVESTOR STUDX, supra note 49, at 1537. See generally id. 1537828. For purposes of Rules 97 and 127 , the block positioning rules, the NYSE defines a block as "a quantity of stock having market value of $\$ 200,000$ or more which is acquired by a member organization on its own behalf and/or for others from one or more buyers or sellers in a single transaction." NYSE Rule 127.10 (Supplementary Material), 2 NYSE GUIDE If 2127 (1972). The NYSE off-floor trading rule, which prohibits members from entering orders to take advantage of price changes caused by a large block, applies whenever any of the persons enumerated in the rule learns about a trade involving 5,000 shares or more. NYSE Rule 112.10(b) (Supplementary Material), 2 NYSE GUDE \2112.10 (1972). ASE Rule 24, discussed at text accompanying notes 211-15 infra, applies to transactions involving 10,000 shares or more.

204 The price impacts of block trades on the NYSE are described in 4 INSTTIUTTONAL INVESTOR STUDY, supra note 49, at 1721-32. The Study found that in minus-tick block trades (trades at a discount from the previous market price) of $\$ 1,000,000$ and over the average price change between the price at the close of the previous day and the block price was a decline of $1.86 \%$. That included a price decline, on the average, of $1.14 \%$ from the price of the trade prior to the block trade to the block trade itself. The Study found that following block trades prices rose on the average by $0.71 \%$ on the same day. Id. 1728-29. 
constitute a substantial majority of block trades executed, ${ }^{205}$ the price change normally is temporary. The Institutional Investor Study concluded that in such block trades the discount from market price is the temporary liquidity cost of moving a large quantity of stock rather than a fundamental repricing of the security involved. ${ }^{208}$ The Study's analyses showed that on the average stock prices recovered very quickly after block trades at a discount, returning to a level very close to the former market price within the same day. ${ }^{207}$ The Study also described the way in which exchange members and particularly floor traders would be able to profit from their knowledge of block trades prior to adoption of the present regulations. ${ }^{208}$ Persons who knew that a block was being shopped could sell short at the current market price and then cover their positions by participating in the block trade, either directly or by means of limit orders on the book, or by making purchases near the discount price directly following the block trade. ${ }^{209}$ Conversely, persons who purchased shares as part of the block trade or close to the discount price could profit by selling those shares when the market price quickly rose. Although such trading theoretically is possible by anyone with knowledge of a substantial block trade, existing exchange commission rates would usually make in and out trading by nonmembers unprofitable. ${ }^{210}$ Floor traders in particular were able to engage in this practice-known as chiseling-because their participation was not necessarily dependent upon prior knowledge that a block trade would occur. Their position on the floor enabled them to respond so quickly to news of a block transaction that often they could purchase part of the block itself or purchase at the discount before the announcement of the block trade was printed on the tape.

Both major exchanges now prohibit such trading by members, member firms, and their employees. ${ }^{211}$ American Stock Exchange rule 24 , which was adopted "to insure that members of the public have an equal opportunity with Exchange members to make investments

205 Id. 1727.

206 Id. 1825; see generally id. 1721-818. The Study concluded that the premium paid in plus-tick blocks, in which the buyer presumably was the active party, constituted a fundamental repricing of the security involved rather than a liquidity cost.

207 Id. 1728-32.

208 Id. 1732-35. The Special Study discussion of floor trading illustrates the possibility for similar trading advantages. See Spectar Studr, supra note 26, pt. 2, at 208 et seq.

2094 Institutionar INvestor Study, supra note 49, at 1603-07.

210 Id. $1729-30,1732$ n.207.

211 The events leading to the adoption of the two-minute rule and other prophylactic rules are described in $5 \mathrm{~L}$. Loss, silpra note 23 , at 3226-27. 
following the execution of block transactions on the Exchange, ${ }^{21212}$ provides:

After learning in any way about any trade in any security executed or about to be executed on the Floor of the Exchange involving 10,000 shares or more, no member or employee of a member or member organization may initiate or transmit or cause to be transmitted to the Floor, for a period of two minutes following the print of such trade on the ticker tape, an order in the same security for an account in which any member or member organization or employee thereof has an interest. ${ }^{213}$

The rule assumes that this market information will have been disseminated adequately within two minutes of its appearance on the tape. ${ }^{214}$

In certain stocks, presumably trades of less than 10,000 shares may cause similar block trading price impacts. Although rule 24 could be read as implying that any transaction not covered is permissible,

212 American Stock Exchange, Info. Circular No. 119-70, at 1 (Dec. 23, 1970).

213 ASE Rule 24, 2 ASE GUDE I 9242B (1972). The comparable NYSE provision is Rule 122.10, the supplementary material to restrictions on registered traders. Although the NYSE provision applies only to off-floor orders, another provision adopted by the Exchange at the same time requires, with certain exceptions, that all orders for the account of a member or member firm, officers and employees of the firm, and discretionary accounts serviced by the member or member firm "be sent to the Floor through a clearing firm's order room or other facilities regularly used for transmission of public customers' orders to the Floor." NYSE Rule 112.10(a) (Supplementary Material), 2 NYSE GUDE II 2112.10 (1972). "The apparent purpose of [this provision] is to insure that member firms trading for their own account do not get a time jump on the public in their placement of orders." 5 L. Loss, supra note 23, at 3227. The Exchange also requires members who are not registered traders and who execute orders for accounts in which they have an interest after they have been on the Floor during the same day to file a weekly report of such transactions. NYSE Rule 112.40(B) (Supplementary Material), 2 NYSE GUDE If 2112.40 (1969); 5 L. LosS, supra note 23, at 3227. By its terms the NYSE two-minute rule is broader than ASE Rule 24, which does not prohibit the entry of orders for discretionary accounts during the prescribed period. However, entry of an order for a discretionary account upon learning of a block trade would seem to conflict with the "ordinary course of business" language used in ASE Rule 24, and entry of the order probably would violate the rule. As mentioned in text accompanying note 210 supra, the Institutional Investor Study found that on the average payment of exchange commissions would make non-member trading in connection with block trades unprofitable.

214 The restrictions of rule 24 do not apply to: (i) an order entered for the purpose of participating in the purchase or sale of the particular block about which the member or employee has learned; (ii) a situation where a Floor Official expressiy invites a member to participate in a difficult market situation; (iii) an order to reduce or liquidate a position acquired pursuant to subparagraph (i) or (ii); (iv) a bona fide arbitrage transaction or a transaction which is part of a purchase and sale or sale and purchase of securities of companies involved in a publicly announced merger, acquisition, tender offer, etc.; (v) a transaction to offset a transaction made in error. Exceptions (i) and (ii) permit members to provide liquidity and thereby reduce the discount or premium accompanying the block trade.

Rule 24 has no analogue governing trading in the over-the-counter market. The reason for that difference may lie in the fact that, in the absence of continuous reporting of transactions, the sale of a block of stock in the over-the-counter market may not have the adverse price impact on subsequent trades which exists in the exchange market. 
the wisdom of such a conclusion is unclear. On the one hand, in the context of governing the action of professionals who are constantly executing trades and who risk serious penalties if they guess wrong, it is desirable for the regulators to draft fairly specific rules. This policy would lead to the conclusion that rule 24 is exclusive. On the other hand, rule 24 may properly be viewed as grounded on the notion that the development under the antifraud rules of principles of equality of access to full and accurate corporate information has a counterpart in the prohibition under the antifraud rules of conduct by persons in the securities business which is not conducive to the promotion of fair and honest markets. ${ }^{215}$

\section{Block Positioners and Over-the-Counter Market Makers}

In contrast to the detailed restrictions on trading by exchange members outlined above, neither exchange nor NASD rules impose comparable limitations upon use of market information by block positioners or over-the-counter market makers. ${ }^{216}$ Over-the-counter market makers position securities from customers in the course of standing ready on a continuous basis to buy or sell stock of a particular company at quoted prices. Registered block positioners ${ }^{217}$ are exchange member firms who facilitate specific customer transactions by taking for the firm account any portion of a block which cannot be accounted for through the firm's upstairs communications system or on the floor of the exchange. Although block positioners normally act for sellers, at times they also sell from their inventory or sell short in order to complete a customer purchase order. In so doing they supplement the specialist in offsetting temporary imbalances in supply and demand, and are exempted from the off-floor trading rules which we have just discussed. ${ }^{218}$

215 Cf. Speciad Study, supra note 24, pt. 2, at 239-40. More than one exchange rule may prohibit trading in connection with a block trade. An American Stock Exchange circular distributed prior to the adoption of ASE Rule 24 stated that sanctions had been taken against a member organization for excessive dealing in a listed security for the member organization's trading account in violation of Exchange Rule $3(a)$. The Exchange circular stated:

The member organization, following a large block transaction, purchased a total of 10,000 shares of the security in four consecutive transactions at successively higher prices in a period of approximately one minute.

In taking this action, the [exchange] found that the member organization and its partner who initiated these transactions had engaged in purchases which were excessive in view of the market for the security. The 10,000 shares constituted substantially more activity than the normal volume for the security. 216 The functions of block positioners and market makers are compared in [Summary Volume] InstrtutronaI, Investor STUDY, supra note 49, at 98-99; see generally 3 id. ch. XII.

217 Block positioners are required by NYSE Rule 127, 2 NYSE Gume II 2127 (1972), to register with the Exchange, and their activities are also governed by NYSE Rule 97, 2 NYSE GuIDE If 2097 (1972). There are no comparable American Stock Exchange rules. 218 NYSE Rule 112.10(b) (ii), 2 NYSE GUDE II 2112.10 (1972); ASE Rule 24(b) (i), 
Over-the-counter market makers on a continuing basis, and block positioners on a sporadic basis, receive confidential market information. For example, market makers learn non-public information about the availability of significant supply or demand for a stock. This data will affect the market maker's decision about the kind of market he is willing to make.

There are no specific restrictions on market makers' or block positioners' use of confidential market information to facilitate their trading activities even though they are not required to assist in the maintenance of a fair and orderly market. In part, this void undoubtedly recognizes that increased information reduces the risks of trading and thus permits narrower markets to be made and better prices to be offered. ${ }^{210}$ In addition, neither the market maker nor the block positioner is given a franchise which affords him an exclusive trading position and an exclusive view of the total flow of the market. There are competing market makers and block positioners. Movement into a particular stock as a market maker is relatively unrestricted. If a market maker or a block positioner acquires a reputation for abusing the information he receives, business will likely flow to his competitors. In addition, in a competitive environment, there is an incentive to make the best market economically possible. ${ }^{220}$

The increasing regulatory emphasis on promoting fairness finds particular expression in efforts to police the operations of the rapidly changing trading markets. The SEC's adoption in January, 1973 of rule $19 \mathrm{~b}-2$, Concerning the Utilization of Membership on National Securities Exchanges for Public Purposes, ${ }^{221}$ is part of a continuing effort to offset the advantages of exchange membership against the assumption of responsibilities to members of the investing public. In 1972 the SEC had sought legislation permitting it to regulate all exchange member off-floor trading because it believed that improved communications gave exchange members the informational advantages

2 ASE GUDE II 9242B (1972). See notes 211-15 supra \& accompanying text. Members who participate in a difficult market situation at the express invitation of a Floor Official are similarly exempted from the off-floor trading rules. NYSE Rule 112.10(b)(i); ASE Rule 24(b) (ii).

219 Although a market-maker must see all of the volume if it is to have the best opportunity to distinguish between temporary and permanent imbalances, that does not mean that it must participate in all the volume. Narrower bid-ask spreads in a central market may well result from greater knowledge of the market and competitive pressures, not from economies of scale.

Feuerstein, Toward A National System of Securities Exchanges, 28 FIN. ANAL. J., May/ June 1972, at 28, 34, reprinted in 4 SEC. L. REV. 525, 533-34 (1972).

220 On certain problems of over-the-counter trading, particularly as related to the NASDAQ system, see Bleakley, Is NASDAQ Really the Answer?, 5 THE INSTrTUTIONAL INVESTOR, July, 1971, at 21, reprinted in 4 SEC. L. REV. 592 (1972).

221 SEC Exchange Act Release No. 9950 (Jan. 16, 1973). 
formerly available to floor traders. The legislation, which was not adopted, would have authorized the SEC to regulate member trading so that such trading would be required to make a "positive contribution" to the operation of the market. ${ }^{222}$ Rule 19b-2 itself stemmed from an expressed concern that certain users of the market by virtue of their economic power may enjoy advantages over other investors. The rule tries to limit that advantage by requiring all trades in the exchange market to be filtered through a broker, the primary purpose of whose membership is the conduct of a public securities business. ${ }^{223}$

222 Letter from William J. Casey, SEC Chairman, to the Hon. Harrison A. Williams, Jr., May 5, 1972.

223 This Article will not discuss the many questions which can be raised about the efficacy of the rule in fulfilling this regulatory objective. 